\title{
DIAGNOSTIC SYSTEM OF PERCEPTION OF NAVIGATION DANGER WHEN IMPLEMENTATION COMPLICATED MANEUVERS
}

Nosov P. S. - PhD, Associate Professor of Navigation and Electronic Navigation Systems Department, Kherson State Maritime Academy, Ukraine.

Zinchenko S. M. - PhD, Senior Lecturer of Ship Handling Department, Head of the Laboratory of Electronic Simulators, Kherson State Maritime Academy, Ukraine.

Popovych I. S. - Dr. Sc., Full Professor of the Department of General and Social Psychology, Kherson State University, Ukraine.

Ben A. P. - PhD, Associate Professor, Deputy Rector for Scientific and Pedagogical Work, Kherson State Maritime Academy, Ukraine.

Nahrybelnyi Y. A. - PhD, Dean of the Department of Navigation at the Kherson State Maritime Academy, Ukraine.

Mateichuk V. M. - Assistant of Ship Handling Department, Head of the Laboratory of Electronic Simulators, Kherson State Maritime Academy, Ukraine.

\section{ABSTRACT}

Context. The article focuses on the question of automated decision-making analysis made by the operator in ergatic systems of critical infrastructures on the example of marine transport control in difficult navigation conditions. It is evident enough that the main criterion for an adequate perception of input information done by an operator is highly likely to predict the choice of behavioral decision-making strategies in discrete time conditions. However, the difficulty of modeling the operator's actions is found to be lying in non-linear pattern of taking definite decisions in emergency situations and deviations from the Codes and Rules.

Objective. The research purpose strategy of conducted investigation can be defined as the development of the mathematical platform for a decision support system (DSS) module with an aim to identify the class-forming set of atomic elements. In particular this issue determines the fact of distortion of the perception of information about navigation risks predicting the operator's behavior pattern while having vessel running process. This is possible to have it depicted through formal analysis.

Method. To capture the analysis of danger perception by the operator the paper introduces a mathematical model of data collection which identifies the fact of perception distortion in the form of attribute space of metadata obtained by the method of converting information from navigation devices. Besides, the factor of disorientation of the operator can be considered to be a shift on a displaced bridge which significantly affects on the analysis of information for adequate decision making. In addition, taking into account the failure of navigation equipment such as: RADAR, ARPA, AIS, ECDIS, especially while doing exit from the automatic control mode, a dangerous precedent can possibly be created for the operator not ready to perceive the complexity of the situation. To make it work a formal analysis was carried out using the extending risks possibility level tasks during the transition under these conditions. In addition to this item, a probabilistic model of perceiving the situation under the conditions of the error set is reported to have been constructed. So, as the result, the modeling process turned out to show the definite evidence of getting no way possibility to have the degree of criticality of the navigation situation determined without a clear identification of factors affecting the distortion of perception of the operator. Nevertheless, generalized statistical data are sure to be not enough and there is a special need of taking into account an individual information model of each operator for the effective work of DSS as this process faces real challenges. It must be significantly noticed that in order to analyze the perception of information by the operator a special test for defining preferences when choosing a strategy of control actions in the form of maneuvering under difficult navigation conditions purpose was created. Regarding the test results, as well as data on the passage of locations, certain attention is advised to be drawn to the classification analysis of 15 parameters using artificial neural networks having been carried out by our team and, as a consequence, the boundaries of deviations in the perception of navigational danger were found out and clarified. Additional superior item to be spoken about is certainly the introduction of rules and algorithms having been welcomed into the DSS core including the following: interaction field, RADAR and NIS synchronization tools; actual navigational hazard in a given cartographic area; ships trajectories and, as a result, simulations of probable deviations in the information perception of the operator.

Results. In order to meet beneficial agreement between the effectiveness of the developed DSS with the proposed formalanalytical approaches an experiment was assumed to be appropriate to be conducted using the Navi Trainer 5000 navigation simulator (NTPRO 5000). Based on the foregoing, due to comprehensive results in experiment metadata for the 2.5 years of operation of navigation simulators and DSS software tools the identification of the deviation probabilities in the information perception of dangers was achieved and export the predicted data to new locations for the operator and cartographic areas was performed. Undoubtedly, the experimental investigation confirmed the hypothesis of the study and reflected completely the feasibility of using this DSS to make predictions of possible risks when control the vessel by analyzing the information model of the operator.

Conclusions. Formal-analytical approaches presented in the study combined with the developed DSS software tools and the information itself made it possible to classify the decision-making strategies of the operator when control the vessel and to predict the probability of catastrophic consequences. The feasibility of the proposed models and methods was successfully revealed by carried out experiments.

KEYWORDS: decision support systems; operator information model; computer navigation simulators; probability of risks; human factor information analysis, automated control systems, automatic control systems. 


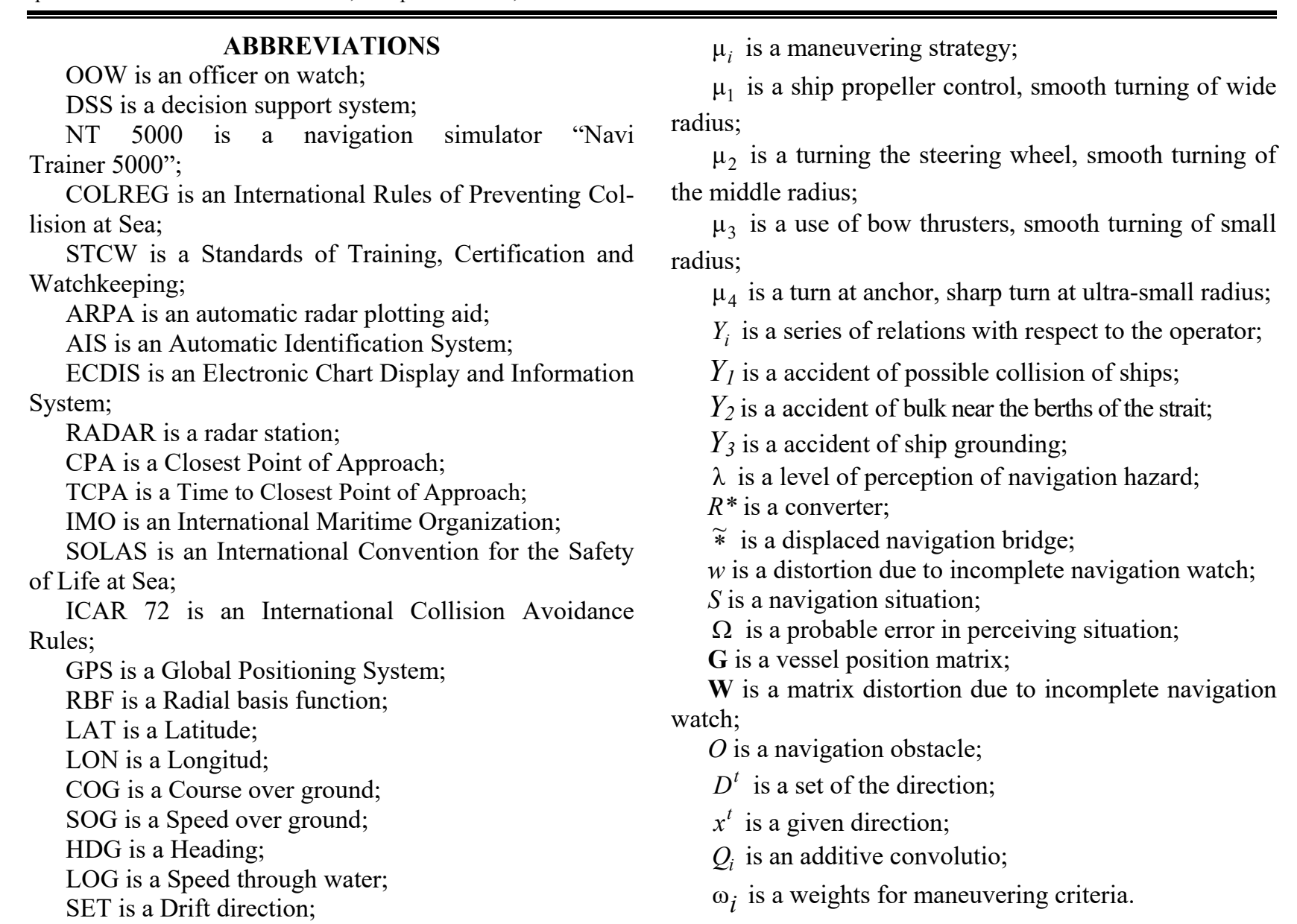

SPD F is a Speed forward;

SPD A is a Speed Aft;

RUD is a Rudder angle;

ROT is a Rate of turn;

$\mathrm{RPM} \mathrm{L}$ is a Revolutions per minute.

\section{NOMENCLATURE}

$f$ is a navigation equipment information;

$A$ is an ahead;

$\xi$ is a rule ID;

$U$ is a navigation tool;

$M^{\prime}$ is a navigational danger;

$L$ is a turn on the left;

$B$ is a backwards;

$R$ is a turn on the right;

$g_{i j}$ is a vessel position;

$\alpha$ is a strategy of movement;

$P_{i j}^{\prime}(\alpha)$ is a probabilities of movement;

$y^{*}$ is a distance from the actual position;

$y$ is a radius of the probable interaction;

$P_{i j}(x)$ is a probabilities of the adjusted direction; sel;

$\varphi$ is a mapping describes the displacement of the ves-

$G$ is a interaction radius;

$\beta_{i j}$ is a framework of the distribution law;

\section{INTRODUCTION}

There is a widely-spread tendency in modern shipping practice for having minimization of sailing costs process accompanied with constant reduction of crews of vessels including navigational staff. Therefore, navigation and control of the ship are conventionally prioritized to be carried out in the context of reducing the number of people, as well as the lack of staff on the navigating bridge. Unfortunately, modern fleet is noticed to reflect the world experience of having nearly two or three people alone on the bridge in heavy navigation cases. In addition, the actual navigation and management of the vessel is mostly performed by one person, to be exactly, by the captain or officer of the watch. It must be taken into account that such a minimum number of people is reviewed to be the most profitable and advantageous way in having poor navigation. Moreover, difficult conditions of emergency situations constantly require additional number of crew members on the last boarder of safe level.

So, to be more precise, general formula of number of peoples to be operating on the bridge can possibly look as follows: OOW; OOW + 1 or Master + OOW + 1.to be.

It must be significantly noticed that in the conditions of entry/exit of the vessel in/from the port, a pilot is sure to be added (if local laws do not permit another scheme). Special emphasis to be done is that the pilot from one point of view is not a responsible person and, from another one, according to all international standards, really 
is a situational member of the navigational team on the bridge. Being ultimate adviser and assistant to the captain he gets used to having additional skills and knowledge in a particular water area. In spite of all mentioned above, the situation seems to be following a pattern according to which most pilots do not perceive themselves to be assistants in this way considering mostly themselves to be an independent leader on the navigation bridge. Such poorly done actions could possibly cause tension between the pilot and the ship's captain and could create negative air on the bridge leading to unpredicted consequences, emergencies and, as a result, unwelcomed stress [1].

It can be clearly seen, speaking about the prioritizing task of vessel moving in the port areas, that each ship is said to have a motion vector in one of three directions directly on the course or in reverse. In spite of this, port areas, passing locations and narrows try to avoid usual practice of the vessel movement in the preferred direction. As the presence of insurmountable cartographic obstacles on the way constraints to the draft of the vessel or a significant amount of maritime traffic there is definitely observed fundamental approach of the operator to propose the altering direction of movement choosing the one on which the obstacles are considered to be minimal [2].

However, being involved into choosing a maneuvering strategy the operator processes with the parameters of movement and location of the vessel based on his own experience [3]. The situation is recognised to be especially disadvantageous becoming aggravated at the time of completion of the dynamic positioning modes and inappropriate watch keeping. These issues leads to the worsening of the process of adequate perception of navigation dangers. It must be emphasised that abruptness and precipitousness of the situations are contributing to the distortion in the risks assessment during the adoption of complex decisions being limited by the time of maneuvering the vessel. Summing up all spoken about, it might be noted that there is definitely a tendency of decreasing level of the safety control in maritime transport to be observed investing to the increases of the probability of shipwrecks.

The emphasis must be placed to the fact of having real troubles in decreasing the occurrence of violations experience leading to distortions in the perception of danger by operators. This item is extremely difficult to be determined without a psychologist involvement into the participation which is a problematic one because of his not being a part of the ship's crew moment. This issue could be possibly solved by the introduction of a specially developed information system which provides control and prevention of negative consequences services.

The object of research is said to be the process of automated identification of distortions in the perception of risks.

The subject of research are models and algorithms implementing the process of automated identification of distortions in the perception of navigational hazards.

The aim of the study is to develop the mathematical platform for a decision support system (DSS) module to identify the class-forming set of atomic elements that determine the fact of distortion of the perception of information about navigation risks through a formal analysis and prediction of the operator's behavior when control a vessel.

The purpose of article is said to be solving the following tasks:

1. To analyze the probabilistic models of the transition of the vessel on the cartography of the location with limitations of the navigation risks relatively to $f$ and the international rules for the management of the vessel according to $A$ when have a watch. To determine the interrelation of $\xi$ and $v$ relatively to the bias $U$, which made the DSS signal, $R \xi$ possible to be revealed.

2. To define in a formal form an incomplete model of perception by operator of $M^{\prime}$ which is characterized by inaccuracy and dependence on variables. This item is reported to require the development of the identification mechanism by means of DSS.

3. To develop a local metric for the transition of the vessel to a new state based on a set of directions: $A, R, C$, $L, B$ - defined by the boundaries $g_{i+1, j}$ and probabilities of movement $P_{i j}^{\prime}(\alpha)$ depending on $y^{*}$, which will determine the probability of the moving vessel in $P_{i j}(x)$.

4. To determine the DSS operation scheme that will provide possibility at a certain given time interval to define discretely the a priori probabilities of the ship's movement $\varphi=\varphi_{2} \circ \varphi_{1}$ in the nearest $G$, proposing several samples of identification of the probable interaction of the ship with navigational hazards $\beta_{i j}$ at the current time at $g_{i j}=1$.

5. To develop an adaptive testing algorithm for cadets aimed to identify operator preferences in the form of $\mu_{i}$ unveiling influence on deviations in the perception of $Y_{i}$, based on Pareto principles of optimal alternatives.

6. To have an experimental investigation done by automated analysis of logfile data of perform maneuvers in the narrowness of the Bosphorus Strait using artificial neural networks.

7. To determine metadata for DSS with an attempt to create an individual operator model designing to be in the form of a preference map based on the analysis of server data of the NTPRO 5000 navigation simulator.

Thus, to be precise, the review papers domain goal with the implementation of all aforesaid tasks can be defined as identification of the stable models of operator behavior developed in experience in certain situations, relative to locations, COLREG rules and ship maneuverability. This detailed information would definitely enable DSS to propose key contributions into the enhancement of the accuracy level of forecasting critical situations.

\section{PROBLEM STATEMENT}

Significant new insights to the definition of the probability of shipwrecks in case of bridge watchkeeping incomplete configuration must be offered and as a result, 
the information tools to prevent them might be practically determined. To have several ambiguities avoided in such situations the rules of the COLREG and STCW are sure to be carefully followed when carrying out the navigation watch.

It must be emphasised that for having these purposes achieved an information module was developed in the previous research papers determining the composition of the watchkeeping team in real time [4] (Fig. $1 \mathrm{a}, \mathrm{b})$. In addition to the spoken above, heart rate and temperature sensors were made use of, indicating the probable stressful condition of the chief officer and second officer on the bridge (Fig. 1 b).

Besides, one more highlighted subject to be paid attention to is tracking the position of crew members due to its being a significant use of while defining the interaction models within the team. Notwithstanding this item, it is troubled enough to determine the forms and boundaries of the perception of the navigation situation by the operator who is responsible for decision making.

The primary perception model of the navigation situation: $\lambda=S f+w$.

The main problematic action is the necessity of additional information tools to meet the needs of the reliability in identification of the navigation situation.

For example, let us take the Radar Station as a device $U$, whose output signal gives the values of the parameters of the navigation situation under study.
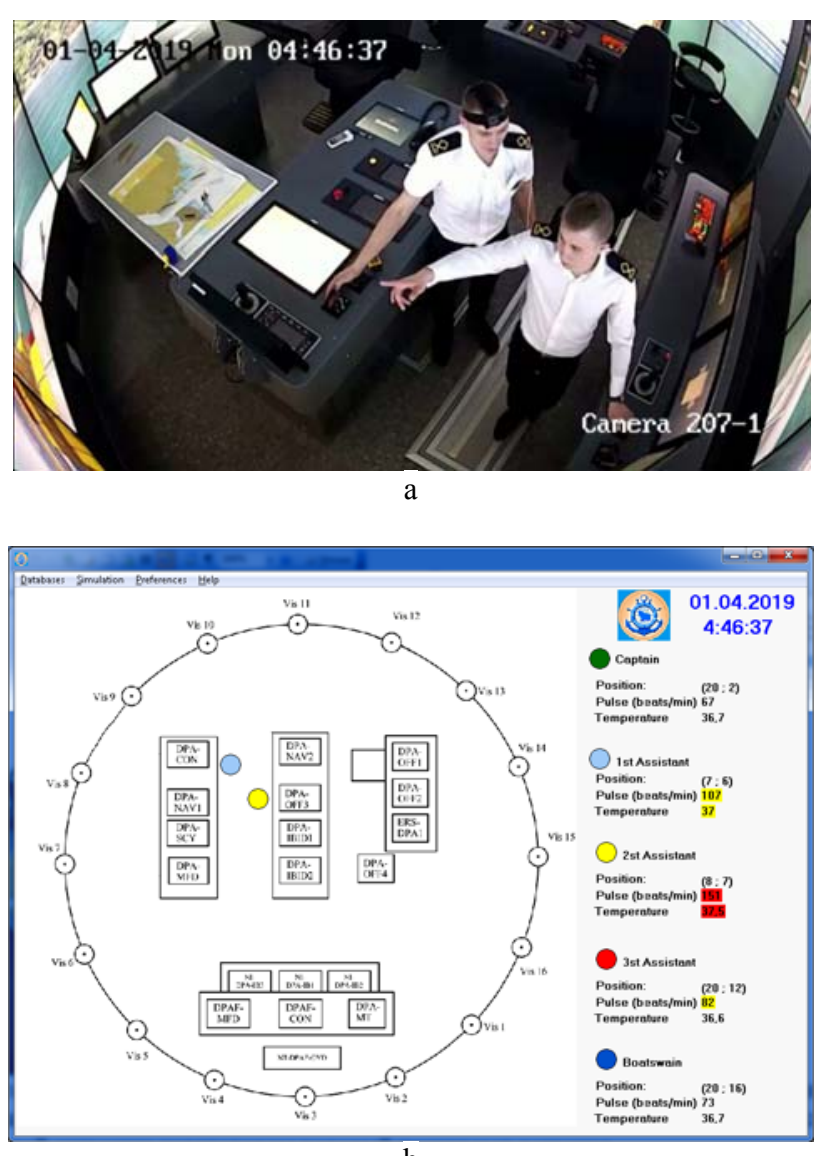

Figure 1 - Incomplete watchkeeping team on the bridge
Then the task of interpreting measurement (1) is reduced to a transformation $\lambda$ to the form characteristic of measurement on the instrument $U$. At the same time, the designed DSS should have such a converter $R^{*}$, which allowed generating the signal $R^{*} \lambda$, as the most accurate $U f$.

Summing up, basing on this model of perception of the navigation we could definitely come up to the conclusion that using a number of synchronized navigation devices such as Radar Station, ARPA, AIS, ECDIS and lack of deviating from the rules of watch keeping lead to beneficially leveled down navigation risks.

However, taking into account the case of poorly performed navigation watch, especially being complicated by the fact of the $\tilde{*}$, it is necessary to build a model under conditions of probable error in $\Omega$ and, as a result, the risks of catastrophic consequences would seem to be increasing (Fig. 2 bridges).

Contemporaneously, the control of navigation equipment cannot be completely rely on as the time ranges of loss of system interaction with the instruments may drive to untimely decisions-making strategy when controlling the vessel. $6]$.

Consider this situation in the mathematical aspect [5,

Let us take an example when the operator analyzed the navigation situation under conditions of incomplete watch keeping and its perception is $\tilde{\lambda}=\widetilde{\Omega} f+\widetilde{w}$, at the same time, this incomplete model of perception $\tilde{\lambda}$, deliberately bears an inaccuracy, then: $\tilde{\lambda}=S f+w \in \mathfrak{R}_{n} \quad$ and $\widetilde{\lambda}=\widetilde{\Omega} f+\widetilde{w} \in \widetilde{\mathfrak{R}}_{\widetilde{n}}$, where $f \in \mathfrak{R}_{m}$. So, an incomplete perception model is clearly seen to be followed such as: $M^{\prime}=\left[\left(\begin{array}{c}S \\ \widetilde{S}\end{array}\right),\left(\begin{array}{cc}\Theta & 0 \\ 0 & \Theta\end{array}\right)\right]$, where $\widetilde{S} \neq \widetilde{\Omega}$, and it's statistically correct to deduce that the distribution is: $\left(\begin{array}{c}w \\ \widetilde{w}\end{array}\right) \rightarrow \aleph\left(\left(\begin{array}{l}0 \\ 0\end{array}\right),\left(\begin{array}{cc}\Theta & 0 \\ 0 & \Theta\end{array}\right)\right)$.

Apparently, it is to be emphasized that without having clear identification of the variables $w$ and $\widetilde{w}$, the process of determination of the degree of perception of the criticality of the navigation situation is looked at as being not a successful one. Therefore, the generalized statistical data as on the individual operator model can be regarded as having a problematic issue to have reliance in [7].

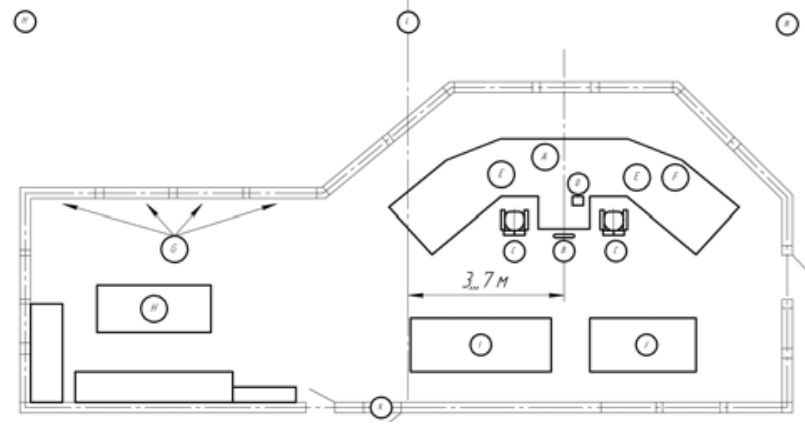

Figure 2 - Offset Bridge Layout

(c) Nosov P. S., Zinchenko S. M., Popovych I. S., Ben A. P., Nahrybelnyi Y. A., Mateichuk V. M., 2020

DOI 10.15588/1607-3274-2020-1-15 
The complexity of making such a model work under the conditions of a number of difficult - to be -determined factors introduces insurmountable obstacles to resolve this problem. In view of above, the development of a decision support system is to obtain an essential value of with an aim of constant monitoring of situations and risks associated with them while keeping navigation watch on the bridge.

It is to be highlighted that operators of maritime transport are in beneficial position due to the monitoring possibility being carried out through RADAR and Nautical Equipment [8] in a location at a $r$, and the opportunity to choose the direction in which they observe the least amount of maritime traffic not speaking about the absence of cartographic obstacles.

In the circumstances of drawing an increased attention to, the operator constantly monitors the field of interaction, which is a combination of two matrices $(\mathbf{G} ; \mathbf{W})$. At the same time $g_{i j}$, the value corresponding to the presence or absence of the vessel in this position: $o_{i j}=\{0 ; 1\}$ the value corresponding to the presence (1) or absence (0) of navigation hazard in this cartographic region.

We introduce a metric on cartography in the form of frames of the nearest radius of movement (Fig. 3.), the direction of motion represents: $D^{t}=\{A, B, L, R\}$.

The operation of moving the vessel is denoted by a variable $\alpha$ taking the values $A, R, L, B$, while the boundaries of the frames in the radius of movement will assume that: $g_{i+1, j}=g_{i j}^{(A)}, g_{i, j+1}=g_{i j}^{(L)} \ldots g_{i j}=g_{i j}^{(C)}$.

For frames with $g_{i j}=1$, we define the probabilities of movement, provided that the vessel moves to the open frame: $P_{i j}^{\prime}(\alpha)=\left(\left(1-g_{i j}^{(\alpha)}\right)\left(1-o_{i j}^{(\alpha)}\right)\right) / 4$.

Besides, by means of automatic recognition of dangerous targets of the Radar Station [9] the function of analyzing the surrounding navigation environment has been introduced.

For example, let us determine the a priori probabilities of the ship moving in the nearest radius of interaction. Simultaneously to this, the cartographic obstacles are

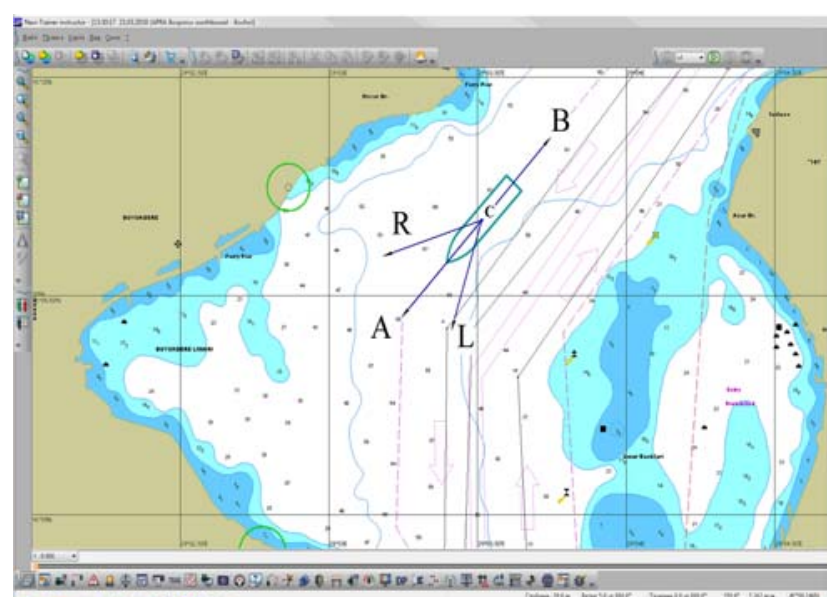

Figure 3 - Ship transition probabilities taken to be expressed as constants and the moving targets could be distributed depending on the perceived navigation hazard:

$$
P_{i j}^{\prime \prime}\left(D^{t}\right)=1-\left(\left(\sum_{k=1}^{y^{*}} g_{i, j+k}+y-y^{*}\right) / y\right) P_{i j}^{\prime}(A),
$$

where $y$ is the radius of the probable interaction of the vessel with navigational hazards.

$y^{*}$, can be considered as a derivative of CPA and TCPA, and $P_{i j}^{\prime}(\alpha)$. The next step to be done is the increase of probability of moving in a given direction $x^{t}=\left\{x^{\prime}, \ldots, x^{\prime \prime \prime}\right\}$.

$$
\begin{gathered}
\left.P_{i j}(x)=P_{i j}^{\prime \prime}(x)+\alpha \min \mid 1-P_{i j}^{\prime \prime}\left(x^{t}\right)\right\rfloor, \\
P_{i j}\left(x^{t}\right)=P_{i j}^{\prime \prime}\left(x^{t}\right)-\left(\alpha \min \left[1-P_{i j}^{\prime \prime}\left(x^{t}\right) \mid / 4\right) .\right.
\end{gathered}
$$

At the same time, $\alpha \in[0 ; 1]$ might be defined as the strategy of movement (maneuvering, the chosen course of the vessel motion, speed).

However, despite of the foregoing, the idea of the metric of real maneuvers assuming not a transition from one frame to another (if this frame is empty)is sure to be accentuated. Moreover, the actions of the operator thus lead to the movement of the vessel in definite time being the choice of strategy. So, new contemporary approaches relating this subject are highly likely to be found out to make it possible to forecast the actions of the operator with sufficient accuracy and the probability of having warning of disasters just in time.

\section{LITERATURE REVIEW}

The dominating strategy in the attempt to increase the efficiency of maritime transport is having capable navigational bridge team [10] taking into account the latest research on the mental state of expectations of professional activities [11]. This way is efficient enough due to safety arrangements in accordance with international standards and the regulations of IMO, SOLAS, STCW, COLREG [12]. As a rule, it is precisely defined that dominating aspect is the negative manifestation of the human factor that affects the outcome of complicated maneuvers when passing locations during the watchkeeping on the captain's bridge [13-16]. Besides, the factors directly affecting each operator [17-19] are obviously not the single ones to have essential impact on, there are factors of the organization of interaction between members of the watch [20-21]. In addition to cartographics and weather conditions [22], certain number of factors depending on insufficient qualifications of the crew becomes vitally important [23]. According to the carried out research, it is to be underlined that the quality of maneuvering is directly affected by the number of simultaneous information signals causing troubles connected with the perception threshold exceeding [16]. However, this investigation is facing

(C) Nosov P. S., Zinchenko S. M., Popovych I. S., Ben A. P., Nahrybelnyi Y. A., Mateichuk V. M., 2020

DOI 10.15588/1607-3274-2020-1-15 
challenges while examining the other side of the situation, namely the distortion of the perception of the shipwreck hazard. These deviations from an adequate perception of navigational danger cause confusing actions to happen being significantly influential on the path of the vessel and, in sum, are likely to generate tragic consequences. Models and methods in the framework of set theory, theory of logic, operations research, game theory, and probability theory can happen to be of great assistance being an operator mathematical description of the decision making process in this area of research [24-26]. The reducing of the composition of the bridge team practically means the expansion risk of a catastrophic situation making the navigation process troublesome to be predicted. Therefore, it would be beneficial to assume that there is a certain need in deeper understanding of the way of the decision-making process of the operator which is greatly influenced by complex formalized factors impossible to be tracked without the help of a qualified psychologist. In addition, in case of incomplete configuration of bridge team, the operator is the only person to be involved into the decision making process and in case of an erroneous action none of the members of the watch will be able to prevent these events from happening [27]. However, there are no vivid evidences in having references to systems able to identify these factors in an automatic way in order to exclude the possibility of occurring disasters in the notorious literature.

\section{MATERIALS AND METHODS}

Based on the foregoing, the purpose of the DSS development requires to be abstract from movements relative to the course of the four options to a much larger area in terms of the time limits for the implementation of maneuvers.

Having number of possible actions expanded could be considered as a problematic issue causing taking into account only relatively typical maneuver.

Regarding that the classic options for avoidance of collision in maritime transport are rare, there may be quite a lot of possible actions. The actual question is about the choice of the most suitable one [28-29].

In fact, the main thing that constitutes a problem of the formal description presents the idea of each operator having his own experience in performing certain maneuvering operations. In this regard, a task comes up in setting up the experience connections that is to be strengthened by the practice of navigation relative to each operator.

The calculated probabilities for each direction of movement determine the state of the interaction model at each stage. The evolution of the $\mathrm{G}$ is represented by the recurrence relation: $G_{n+1}=\varphi\left(G_{n}\right)$, where $\varphi=\varphi 2 \circ \varphi 1$. Then for each interaction frame, such that $g_{i j}=1$, we introduce a variable $\beta_{i j}$ within the framework of the distribution law.

The mapping $\varphi 1$ describes the displacement of the vessel to free cartographic areas within the framework of the COLREG rules. It does not obligatory mean the likelihood of becoming this area the target of maneuvers of other vessels. In turn, the mapping $\varphi 2$ is introduced in order to define the course combinations of the vessels in the nearest range of actions. In order to resolve the effects of mappings $\varphi 1$ and $\varphi 2$ on the considered formal model, we present the following sequence of DSS work (Fig. 4).

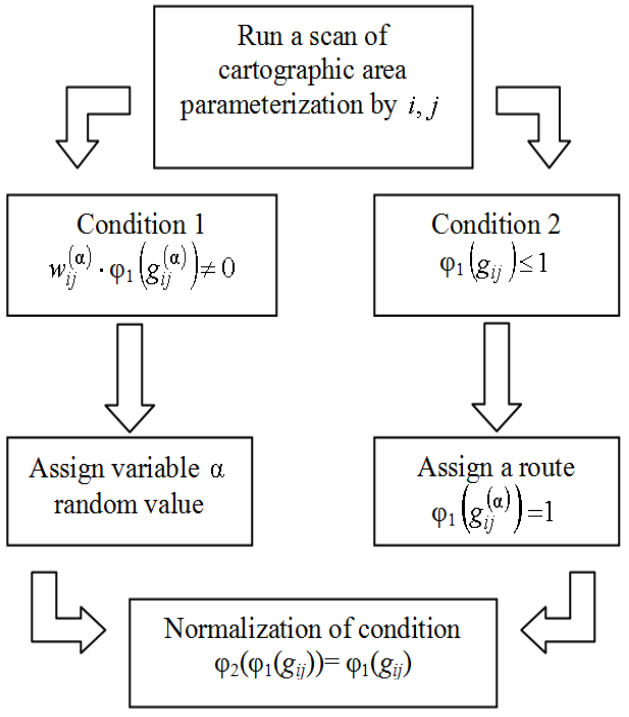

Figure 4 - DSS workflow for identifying probabilistic risks

However, the real ambiguity is that the danger lies within the possible operator fallaciousness who is likely to perceive the navigation situation in his own way and, as a result, the risk of a crash in case of a chosen trajectory is triggered to get the wrong turn. Consequently therefore, the main factor influencing on taking the wrong strategy direction is supposed to be stable experience connections. This issue possesses inconsistent nature when taking into account the bundle of existing rules and recommendations of international shipping regulations.

Hence, in such case, the task of the DSS that needs to be accomplished is to clearly identify the data of destructive relationships from the scratch while performing simulator training on cadets or undergoing re-certification by a crew having more than 10 years of experience.

For the particular purpose of this item, an algorithm was developed and taken to include a specialized adaptive test and synchronization tools with navigation simulators. Being of a particular importance, with regard to getting these issues accomplished, they are aimed at identifying the investigated deviation factors in the perception of navigation danger.

This algorithm provided the possibility to have been testing 351 cadets of the Kherson State Maritime Academy for more than two years of navigational tasks. The results depicted that at the time of making a decision from three to four possible maneuvering strategies of the vessel happen to be made mostly use of. It must be added that this set of strategies is due to positive experience and does not meet any contradictions with the rules of the ICAR 
72. Moreover, there are a number of criteria regarding the performance functions of the maneuver to complete a complex turn using the example of the Bosphorus Strait. Thus, a set of alternatives for decision making is formed $Y_{1}, \ldots, Y_{3}$.

In a survey of cadets and experienced operators, three performance criteria being inverse to the risks of shipwrecks are named to be the most clearly distinguished.

So, we need a mathematical model to be constructed in terms of the Pareto efficiency theory [30].

It is worth mentioning that DSS during multiple passage of locations and performing maneuvers finds out the most widely spread behavior pattern of the cadet (operator) in typical situations. Apparently, it is true to say that multiple repetition of successful maneuvers in similar situations would lead to reinforcement of the situationmaneuver combination in reference to each operator. Thus, an array of preferences is formed regarding each alternative within the navigation situation.

So during the experiment, the DSS determined the following series of relations in reference to the operator:

$$
\begin{gathered}
Y_{1}: \mu_{1} \approx \mu_{2} ; \mu_{2}, \mu_{1} \succ \mu_{3} ; \mu_{3}, \mu_{2}, \mu_{1} \succ \mu_{4}, \\
Y_{2}: \mu_{2} \succ \mu_{1} ; \mu_{2} \approx \mu_{3} ; \mu_{4} \approx \mu_{1} ; \mu_{3} \succ \mu_{1} ; \mu_{2}, \mu_{3} \succ \mu_{4}, \\
Y_{3}: \mu_{2} \succ \mu_{1} ; \mu_{2} \succ \mu_{3} ; \mu_{2} \succ \mu_{4} ; \mu_{3} \approx \mu_{4} ; \mu_{1} \succ \mu_{3} ; \mu_{1} \succ \mu_{4} .
\end{gathered}
$$

As for the operator himself, he fronts the question of having the most suitable option to be chosen from taking into account the criteria, using $Q_{1}, Q_{2}$.

For $Q_{2}$, weights were selected for the criteria regarding the experience of performing maneuvers: $\omega_{1}=0,5 ; \omega_{2}=0,2 ; \omega_{3}=0,3$.

For each of the criteria, the DSS constructs a relationship matrix. $Y_{1, \ldots, 3}$.

Introduce the rule:

$$
\xi_{Q}\left(\mu_{i}, \mu_{j}\right)=\left\{\begin{array}{l}
1, \text { if } \mu_{i} \geq \mu_{j} \text { or } \mu_{i} \approx \mu_{j} \\
0, \text { if } \mu_{i} \prec \mu_{j} .
\end{array}\right.
$$

Then, the relationship matrix $Y_{1, \ldots, 3}$ will have the form:

$$
\begin{aligned}
& \xi_{q_{i}}\left(\mu_{i}, \mu_{j}\right)_{Y_{1}}=\left|\begin{array}{llll}
1 & 1 & 1 & 1 \\
1 & 1 & 1 & 1 \\
0 & 0 & 1 & 1 \\
0 & 0 & 0 & 1
\end{array}\right| \text {, for } \omega_{1}=0.5, \\
& \xi_{q_{i}}\left(\mu_{i}, \mu_{j}\right)_{Y_{2}}=\left|\begin{array}{llll}
1 & 0 & 0 & 1 \\
1 & 1 & 1 & 1 \\
1 & 1 & 1 & 1 \\
1 & 0 & 0 & 1
\end{array}\right|, \text { for } \omega_{1}=0.2, \\
& \xi_{q_{i}}\left(\mu_{i}, \mu_{j}\right)_{Y_{3}}=\left|\begin{array}{llll}
1 & 0 & 1 & 1 \\
1 & 1 & 1 & 1 \\
0 & 0 & 1 & 1 \\
0 & 0 & 1 & 1
\end{array}\right|, \text { for } \omega_{1}=0.3 .
\end{aligned}
$$

Convolution of relations will be equal:

$$
Q_{1}=Y_{1} \bigcap Y_{2} \bigcap Y_{3}=\left|\begin{array}{llll}
1 & 0 & 0 & 1 \\
1 & 1 & 1 & 1 \\
0 & 0 & 1 & 1 \\
0 & 0 & 0 & 1
\end{array}\right| .
$$

Then the subset of non-dominated alternatives will be equal:

$$
\begin{gathered}
\xi_{Q_{i}}^{\prime}\left(\mu_{i}\right)=1-\sup _{\mu_{j} \in \Sigma}\left\{\xi_{Q_{i}}\left(\mu_{j}, \mu_{i}\right)-\xi_{Q_{i}}\left(\mu_{i}, \mu_{j}\right)\right\} ; \\
\xi_{Q_{i}}^{\prime}\left(\mu_{1}\right)=1-\sup \{1-0 ; 0-0 ; 0-1\}=0, \\
\xi_{Q_{i}}^{\prime}\left(\mu_{2}\right)=1-\sup \{0-1 ; 0-1 ; 0-1\}=1, \\
\xi_{Q_{i}}^{\prime}\left(\mu_{3}\right)=1-\sup \{0-0 ; 1-0 ; 0-1\}=0, \\
\xi_{Q_{i}}^{\prime}\left(\mu_{4}\right)=1-\sup \{1-0 ; 1-0 ; 1-0\}=0 .
\end{gathered}
$$

In this way, $\xi_{Q_{i}}^{\prime}\left(\mu_{i}\right)=[0 ; 1 ; 0 ; 0]$.

Find $Q_{2}$ :

$$
\xi_{Q_{2}}\left(\mu_{i}, \mu_{j}\right)=\sum_{j=1}^{m} \omega_{j} \xi_{j}\left(\mu_{i}, \mu_{j}\right), \sum_{j=1}^{m} \omega_{j}=1, \omega_{j} \geq 0 .
$$

The additive convolution of relations $Y_{1, \ldots, 3}$ will be equal to:

$$
\xi_{q_{i}}\left(\mu_{i}, \mu_{j}\right)_{Y_{1, \ldots, 3}}=\left|\begin{array}{cccc}
1 & 0.6 & 0.6 & 1 \\
0.4 & 1 & 0.7 & 0.4 \\
0.4 & 0.7 & 1 & 0.4 \\
0.6 & 0.6 & 0.6 & 1
\end{array}\right| .
$$

7. Find a subset of non-dominant alternatives for $Q_{2}$ :

$$
\begin{aligned}
& \xi_{Q_{2}}^{\prime \prime}\left(\mu_{i}\right)=1-\sup _{\mu_{j} \in \Sigma}\left\{\sum_{j=1}^{m} \xi_{Q_{2}}\left(\mu_{j}, \mu_{i}\right)-\xi_{Q_{2}}\left(\mu_{i}, \mu_{j}\right)\right\} ; \\
& \xi_{Q_{2}}^{\prime \prime}\left(\mu_{1}\right)=1-\max \{(1-0.5) ;(0.2-0.7) ;(0.2-1)\}=0.5, \\
& \xi_{Q_{2}}^{\prime \prime}\left(\mu_{2}\right)=1-\max \{(0.5-1) ;(0.2-1)(0-1)\}=1, \\
& \xi_{Q_{2}}^{\prime \prime}\left(\mu_{3}\right)=1-\max \{(0.7-0.2) ;(1-0.2) ;(0.3-1)\}=0.2, \\
& \xi_{Q_{2}}^{\prime \prime}\left(\mu_{4}\right)=1-\max \{(1-0.2) ;(1-0) ;(1-0.3)\}=0 .
\end{aligned}
$$

In this way, $\xi_{Q_{2}}\left(\mu_{i}\right)=[0.5 ; 1 ; 0.2 ; 0]$.

The last step to be spoken about in determining the choice of a maneuvering strategy by the operator is to find the intersection of the sets $Q_{1}^{\prime \prime}, Q_{2}^{\prime \prime}$ i.e., $Q^{\prime \prime}=Q_{1}^{\prime \prime} \bigcap Q_{2}^{\prime \prime}$.

As a result, we obtain a decision-making model for the operator regarding the four strategies considered:

$$
\xi_{Q}^{\prime \prime}\left(\mu_{i}\right)=\min \left\{\xi_{Q_{1}}^{\prime \prime}\left(\mu_{i}\right), \xi_{Q_{2}}^{\prime \prime}\left(\mu_{i}\right)\right\}_{Q}^{\prime \prime}=\left|\begin{array}{l}
\mu_{1}=0.5 \\
\mu_{2}= \\
\mu_{3}=0.2 \\
\mu_{4}=0
\end{array}\right| .
$$


$t$ follows from the model that for this operator the strategy " $\mu_{2}$ - turning the steering wheel feather, smooth turning of the average radius" will be most acceptable, strategies $\mu_{1}$ and $\mu_{3}$ are significantly less likely, and $\mu_{4}$ is not considered at all acceptable.

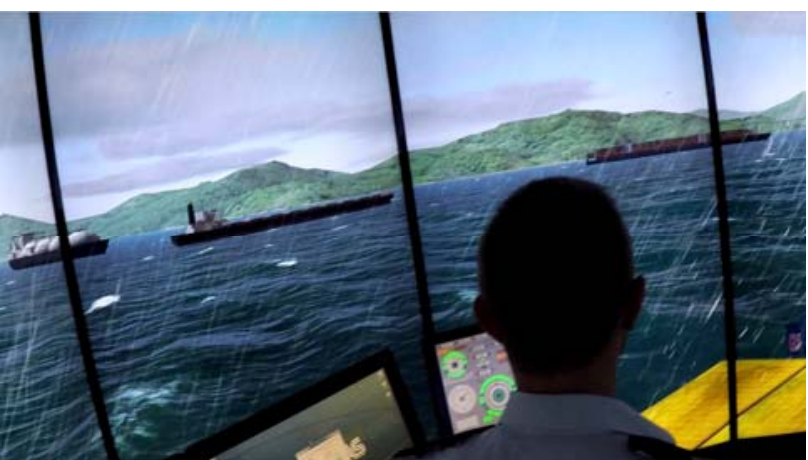

Figure 5 - Increased perception difficulty due to worsening weather conditions

Then, the next stage of the DSS to be determined is the ratio specification of the expected actions of the skipper. Nevertheless, it could be a problematic one due to unpredictable nature of his decision-making strategy. To have the DSS operating on more profound level it is necessary to reach an agreement on specific terms of an experiment conduct with a sample sufficient for adequate conclusions. This effect may possibly be increased with changing weather conditions (Fig. 5). Such cognitive connections are likely to be traced from the very starting points of vocational training and certification. This particular practice having valuable and advantageous nature will definitely help to prevent negative consequences [31].

\section{EXPERIMENTS}

Essential stress must be added to the fact that to cover the aim of creating models of the DSS skipper's behavior, an analysis of the passage of the Bosphorus Strait with a view to completing a complex turn near Sariyer was sampled and successfully accomplished. Latitude and longitude data were processed with a discrete step of 5 seconds and GPS positioning - 1 meter (Table 1).

So, in order to obtain and effectively classify the trajectories by curvature statistical analysis of the data was under specific consideration to support the previous statement.

For sufficient accuracy, a second-level test site was applicable (Fig. 6).

Table 1 - Fragment of DSS database for the analysis of the ma-

$$
\text { neuver trajectory }
$$

\begin{tabular}{|r|r|r|r|r|r|r|r|r|}
\hline TIME_ & LAT & LON & LOG & SOG & HDG & LOG & SET_ \\
\hline & 505 & $10,9375636228,96702804$ & 192 & 20,194 & 192 & 20,194 & 282 \\
\hline & 506 & 10,93664822 & 28,9667649 & 192 & 20,195 & 192 & 20,195 & 282 \\
\hline 507 & $10,9357319428,96650331$ & 192 & 20,197 & 192 & 20,197 & 282 \\
\hline 508 & $10,9348156128,96624328$ & 192 & 20,198 & 192 & 20,198 & 282 \\
\hline & 509 & $40,9338993428,96598482$ & 192 & 20,172 & 192 & 20,172 & 282 \\
\hline & 510 & $40,93298328,96572793$ & 192 & 20,201 & 192 & 20,201 & 281 \\
\hline
\end{tabular}

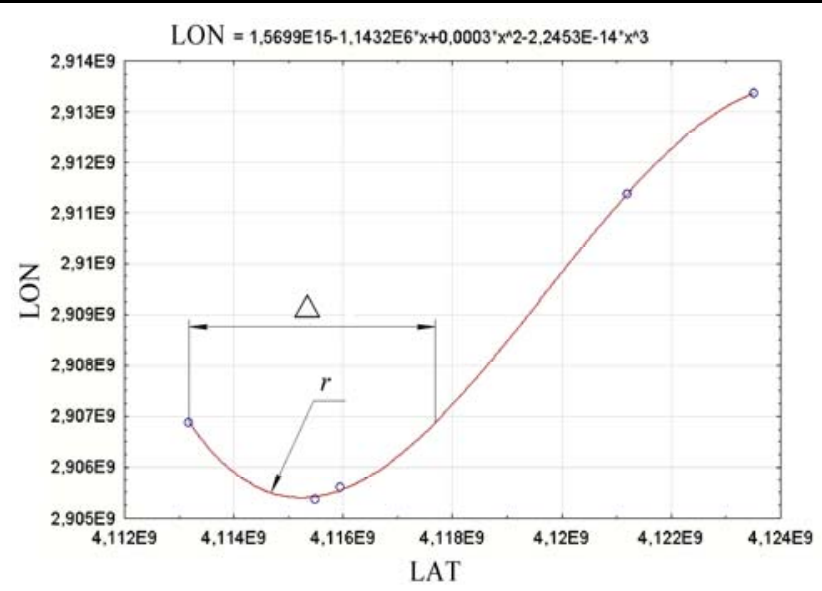

Figure 6-Maneuver curvature graph

The resulting graph determines the delta dimension $\Delta=(4.113 \mathrm{E} 9 \div 4.117 \mathrm{E} 9)$, which allowed us to determine the curvature of the ship's trajectory.

The next step involved raising awareness of identifying four types of trajectories according to the chosen maneuvering strategies (Fig. 7-10).

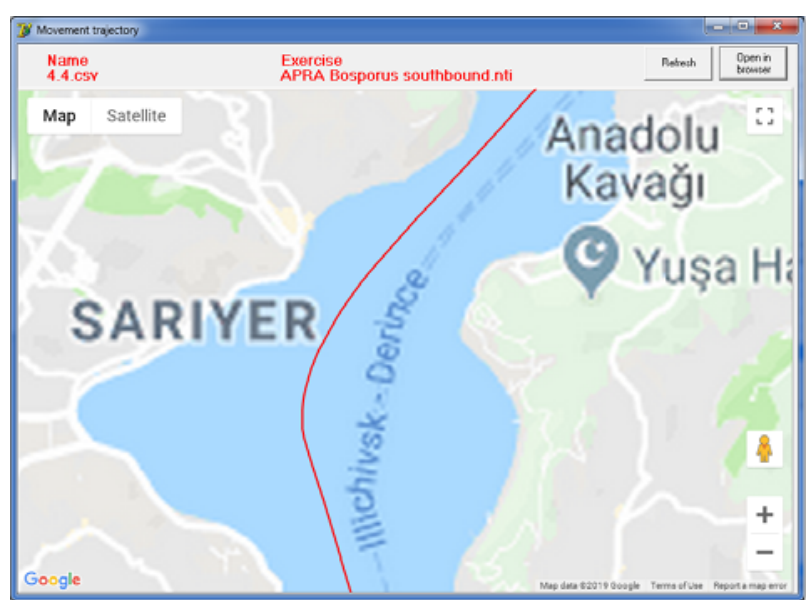

Figure 7 - Turning in a wide arc, $\mu_{1}$

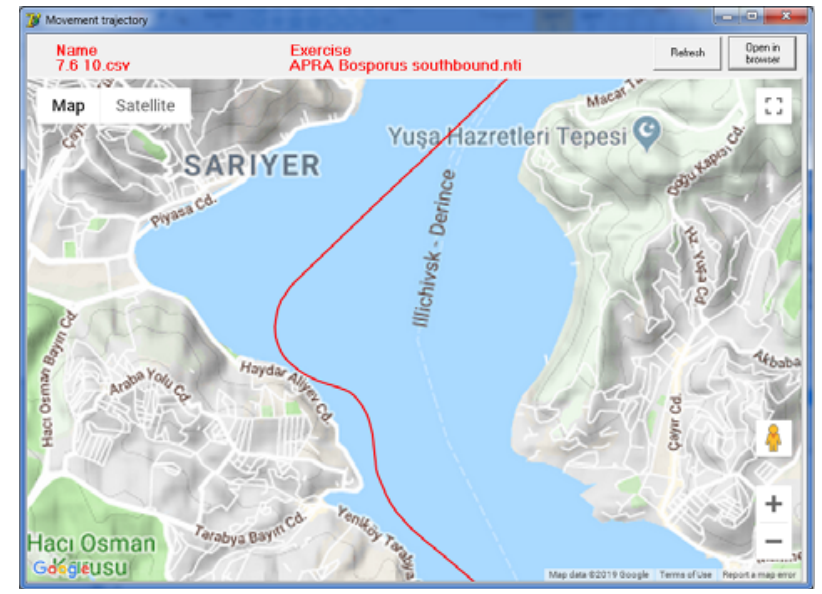

Figure 8 - Medium turning radius, $\mu_{2}$ 


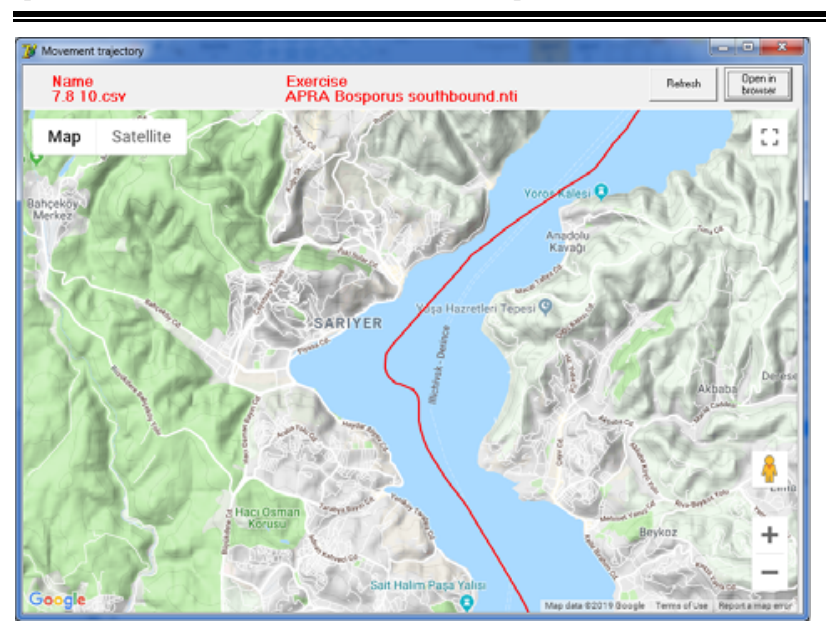

Figure 9 - Small radius turning, $\mu_{3}$

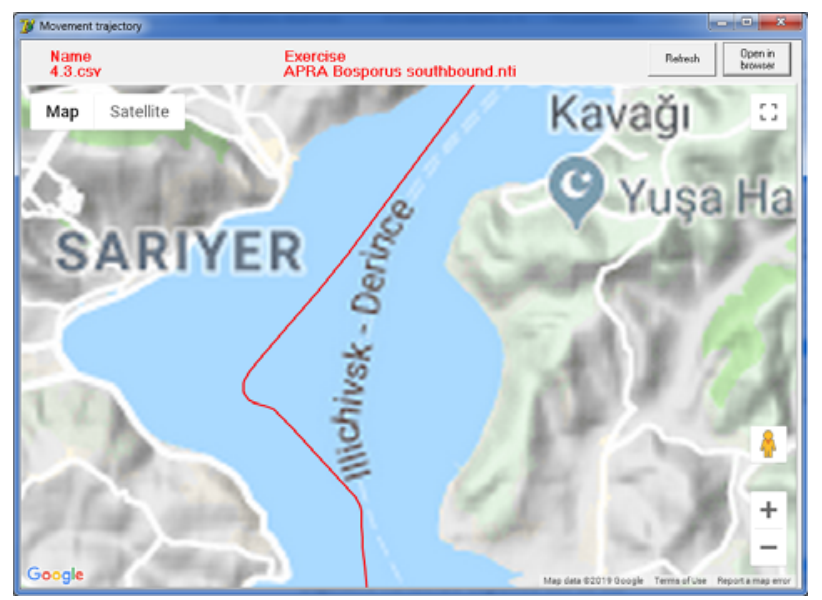

Figure 10 - Turning with the anchor drop, $\mu_{4}$

The initial analysis according to the scattering diagram showed the following results (Fig. 11).

Thus, it was established that it is necessary to take the data slice of the server of the NTPRO 5000 navigation simulator in latitude at 41.150000 .

On this line, the turn maneuver is depicted to be performed directly; therefore, a series of data is the most relevant.

To be precise, the slice for each of the 34 experiments is declared to contain 15 parameters (Table 2).

Scatterplot of $\mu$ against $\Delta$ categorized by LAT and LON

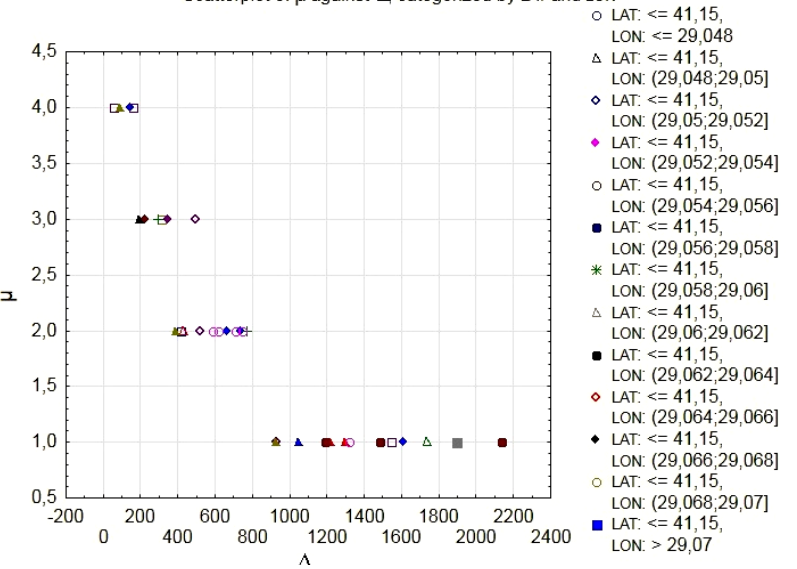

Figure 11 - Multiple scatter diagram of ship locations relative to strategies
According to the provided above table, as it can be seen, the graph indicates a significant spread in $\Delta$ and even the overlap between $\mu_{1}, \mu_{2}$ and $\mu_{3}$. Therefore, other essential aspect for presenting accurate classification, as it deems necessary and advisable, is to get benefit of using deeper nonlinear classification methods.

Nevertheless, the initial stage with 2000 epochs and 5 hidden neurons did not seem to exhibit high efficiency (Table 3).

It is worth mentioning that being one of the most powerful mathematical apparatuses automated artificial neural networks proposes you to be allowed to work with multi-criteria and massive experimental data such as in this case [32-33].

Upon the conclusion of the first stage in the second one which is named as the use of artificial neural networks the parameters were significantly increased: the training covered fifteen networks (which is the maximum number for this experiment); the number of eras was 5000 ; the number of hidden neurons -15 ; a radial basis function was chosen.

Table 3 - Results of the primary classification stage

\begin{tabular}{|c|c|l|l|l|}
\hline Nets & Architecture & Performance & $\begin{array}{c}\text { Performance } \\
\text { Control }\end{array}$ & $\begin{array}{c}\text { Performance } \\
\text { Test }\end{array}$ \\
\hline 11 & RBF 14-12-4 & 41,666667 & 50,000000 & 50,000000 \\
\hline 12 & RBF 14-12-4 & 66,666667 & 0,0000000 & 0,0000000 \\
\hline 13 & RBF 14-12-4 & 50,000000 & 50,000000 & 0,0000000 \\
\hline 14 & RBF 14-12-4 & 41,666667 & 50,000000 & 100,00000 \\
\hline 15 & RBF 14-12-4 & 75,000000 & 50,000000 & 50,000000 \\
\hline
\end{tabular}

In this case, the results of the classification are noticed to show high efficiency level in training networks in the range 16.RBF (14154) - $18 \mathrm{RBF}$ (14154) having the last one as the most effective among them (Table 4).

The confidence level was found out to be 0.999996 being able to be classified as a high indicator for the results (Fig. 12). To some extent, such an indicator can be considered to be a satisfactory one for the experiment and can be taken as a basis.

Table $4-\mu_{i}$ (Summary of classification) Educational

\begin{tabular}{|l|c|c|c|c|c|}
\hline \multicolumn{1}{|c|}{ Architecture } & $\mu-1$ & $\mu-2$ & $\mu-3$ & $\mu-4$ & $\mu$-all \\
\hline 16.RBF 14-15-4 & 7,0 & 4,0 & 3,0 & 2,0 & 16,0 \\
\hline Right & 7,0 & 4,0 & 2,0 & 1,0 & 14,0 \\
\hline Wrong & 0,0 & 0,0 & 1,0 & 1,0 & 2,0 \\
\hline Right (\%) & 100,0 & 100,0 & 66,6 & 50,0 & 87,5 \\
\hline Wrong (\%) & 0,0 & 0,0 & 33,3 & 50,0 & 12,5 \\
\hline 17. RBF 14-15-4 & 7,0 & 4,0 & 3,0 & 2,0 & 16,0 \\
\hline Right & 7,0 & 3,0 & 3,0 & 2,0 & 15,0 \\
\hline Wrong & 0,0 & 1,0 & 0,0 & 0,0 & 1,0 \\
\hline Right (\%) & 100,0 & 75,0 & 100,0 & 100,0 & 93,75 \\
\hline Wrong (\%) & 0,0 & 25,0 & 0,0 & 0,0 & 6,25 \\
\hline 18.RBF 14-15-4 & 7,0 & 4,0 & 3,0 & 2,0 & 16,0 \\
\hline Right & 7,0 & 4,0 & 3,0 & 2,0 & 16,0 \\
\hline Wrong & 0,0 & 0,0 & 0,0 & 0,0 & 0,0 \\
\hline Right (\%) & 100,0 & 100,0 & 100,0 & 100,0 & 100,0 \\
\hline Wrong (\%) & 0,0 & 0,0 & 0,0 & 0,0 & 0,0 \\
\hline
\end{tabular}


e-ISSN 1607-3274 Радіоелектроніка, інформатика, управління. 2020. № 1 p-ISSN 2313-688X Radio Electronics, Computer Science, Control. 2020. № 1

Table 2 - Data for analysis

\begin{tabular}{|c|c|c|c|c|c|c|c|c|c|c|c|c|c|c|}
\hline LAT & LON & $\mathrm{COG}$ & SOG & HDG & LOG & SET & DRIFT & SPD F & SPD A & RUD & ROT & RPM L & $\Delta$ & $\mu_{i}$ \\
\hline 41.15007 & 29.0694 & 180 & 13.679 & 183 & 13.659 & 93 & 0.6 & -0.278 & -1.019 & 1 & 17 & 198 & 1543 & 1 \\
\hline 41.15021 & 29.05515 & 191 & 17.849 & 188 & 17.812 & 277 & 1.1 & -0.635 & 2.899 & -15 & -31 & 119 & 518 & 2 \\
\hline 41.15027188 & 29.05443907 & 186 & 18.152 & 181 & 18.073 & 270 & 1.7 & -0.389 & 3.749 & -8 & -36 & 120 & 931 & 1 \\
\hline 41.1501253 & 29.05949366 & 163 & 19.565 & 161 & 19.557 & 251 & 0.6 & 0.041 & 1.1 & 0 & -14 & 175 & 621 & 2 \\
\hline 41.15003105 & 29.05948225 & 186 & 17.47 & 181 & 17.397 & 271 & 1.6 & -0.155 & 3.31 & 0 & -30 & 118 & 589 & 2 \\
\hline 41.1502799 & 29.05739313 & 182 & 19.025 & 180 & 19.015 & 270 & 0.6 & -0.466 & 1.749 & 1 & -31 & 174 & 1216 & 1 \\
\hline 41.15009557 & 29.06968935 & 187 & 13.3 & 187 & 13.29 & 110 & 0 & -0.027 & -0.058 & 1 & 0 & 196 & 162 & 4 \\
\hline 41.15009869 & 29.05354389 & 144 & 14.475 & 143 & 14.472 & 233 & 0.3 & 0.584 & -0.072 & 15 & 5 & 114 & 189 & 3 \\
\hline 41.15016964 & 29.05770643 & 134 & 13.369 & 137 & 13.355 & 46 & 0.6 & 1.142 & -2.407 & 7 & 49 & 174 & 151 & 4 \\
\hline 41.15016259 & 29.05944346 & 163 & 15.011 & 164 & 15.011 & 73 & 0.1 & -0.047 & -0.225 & -2 & 1 & 100 & 1322 & 1 \\
\hline 41.15205802 & 29.05609934 & 176 & 15.444 & 178 & 15.44 & 87 & 0.4 & 0.678 & -1.393 & 1 & 29 & 174 & 1045 & 1 \\
\hline 41.15010354 & 29.05782304 & 178 & 11.161 & 179 & 11.16 & 88 & 0.2 & -0.058 & -0.262 & 0 & 1 & 99 & 741 & 2 \\
\hline 41.15051669 & 29.05719364 & 207 & 13.925 & 195 & 13.61 & 284 & 2.9 & -1.02 & 6.794 & -35 & -69 & 115 & 293 & 3 \\
\hline 41.15037118 & 29.06389709 & 195 & 15.277 & 206 & 15.001 & 116 & 2.9 & 0.487 & -6.228 & 5 & 94 & 174 & 226 & 3 \\
\hline 41.15007018 & 29.05687433 & 178 & 16.997 & 174 & 16.968 & 264 & 1 & -0.762 & 2.756 & -10 & -49 & 174 & 667 & 2 \\
\hline 41.15007823 & 29.05126307 & 168 & 15.818 & 160 & 15.664 & 249 & 2.2 & -0.369 & 4.725 & -8 & -45 & 117 & 428 & 2 \\
\hline 41.15012971 & 29.05769572 & 171 & 10.845 & 171 & 10.844 & 81 & 0.1 & 0.159 & -0.265 & 7 & 3 & 72 & 1615 & 1 \\
\hline 41.15008146 & 29.06489771 & 180 & 9.098 & 179 & 9.094 & 266 & 0.1 & -0.029 & 0.23 & -1 & -6 & 157 & 1732 & 1 \\
\hline 41.15057277 & 29.06263983 & 167 & 18.085 & 167 & 18.084 & 257 & 0.1 & -0.227 & 0.376 & 2 & -8 & 174 & 89 & 4 \\
\hline 41.15040316 & 29.04961019 & 174 & 9.064 & 157 & 8.686 & 247 & 2.6 & 0.168 & 5.013 & -35 & -38 & 90 & 414 & 2 \\
\hline 41.15048491 & 29.06069001 & 180 & 14.069 & 183 & 14.06 & 92 & 0.6 & -0.476 & -0.732 & -11 & 5 & 193 & 352 & 3 \\
\hline 41.15056649 & 29.06322449 & 201 & 15.433 & 211 & 15.184 & 121 & 2.8 & 1.019 & -6.545 & 18 & 106 & 174 & 926 & 1 \\
\hline 41.15009548 & 29.05537871 & 162 & 13.956 & 162 & 13.96 & 72 & 0.2 & 0.077 & -0.388 & 2 & 4 & 111 & 311 & 3 \\
\hline 41.15094074 & 29.05385945 & 152 & 2.192 & 146 & 2.175 & 235 & 0.3 & -0.224 & 0.74 & 0 & -13 & 175 & 56 & 4 \\
\hline 41.15050148 & 29.0625829 & 142 & 15.32 & 144 & 15.312 & 53 & 0.5 & 0.393 & -1.351 & 10 & 15 & 110 & 387 & 2 \\
\hline 41.15012403 & 29.0613634 & 167 & 13.527 & 168 & 13.52 & 79 & 0.2 & -0.195 & -0.278 & 0 & 1 & 195 & 1484 & 1 \\
\hline 41.15016 & 29.06152 & 169 & 18.036 & 169 & 18.036 & 259 & 0 & -0.215 & 0.26 & -10 & -4 & 119 & 1189 & 1 \\
\hline 41.15011 & 29.0585 & 186 & 17.236 & 182 & 17.184 & 272 & 1.3 & -0.154 & 2.823 & 0 & -26 & 119 & 711 & 2 \\
\hline 41.15026906 & 29.05745309 & 161 & 19.645 & 160 & 19.639 & 250 & 0.5 & -0.075 & 1.063 & -4 & -15 & 175 & 1294 & 1 \\
\hline 41.15015 & 29.05846 & 175 & 15.063 & 173 & 15.055 & 262 & 0.5 & -0.268 & 1.233 & -5 & -11 & 123 & 746 & 2 \\
\hline 41.15003919 & 29.06218542 & 191 & 11.127 & 189 & 11.123 & 279 & 0.3 & -0.508 & 1.14 & -30 & -14 & 86 & 1896 & 1 \\
\hline 41.15007333 & 29.06011754 & 185 & 8.458 & 183 & 8.452 & 272 & 0.3 & -0.16 & 0.784 & -10 & -8 & 50 & 2136 & 1 \\
\hline 41.15044 & 29.0576 & 169 & 15.374 & 166 & 15.363 & 256 & 0.6 & -0.315 & 1.479 & -2 & -14 & 123 & 768 & 2 \\
\hline 41.15026 & 29.05534 & 148 & 13.976 & 146 & 13.966 & 236 & 0.5 & 0.443 & 0.583 & 11 & -1 & 98 & 494 & 3 \\
\hline
\end{tabular}

\begin{tabular}{|c|c|c|c|c|c|c|c|c|c|c|c|c|c|}
\hline $\begin{array}{l}\text { No. } \\
\text { observations }\end{array}$ & $\begin{array}{l}\text { DRIFT } \\
\text { Entry }\end{array}$ & $\begin{array}{l}\text { SPD F } \\
\text { Entry }\end{array}$ & $\begin{array}{l}\text { SPD A } \\
\text { Entry }\end{array}$ & $\begin{array}{l}\text { RUD } \\
\text { Entry }\end{array}$ & $\begin{array}{l}\text { ROT } \\
\text { Entry }\end{array}$ & $\begin{array}{l}\text { RPM L } \\
\text { Entry }\end{array}$ & $\begin{array}{c}\Delta \\
\text { Entry }\end{array}$ & $\mu$ & $\begin{array}{r}\mu-\text { Entry } \\
18 . R B F \\
14-15-4\end{array}$ & $\stackrel{\mu-1}{\text { 18.RBF } 14-154}$ & 18. RBF 14-15-4 & $\begin{array}{c}\mu-3 \\
\text { 18. RBF } 14-15-4\end{array}$ & $\begin{array}{l}\mu-4 \\
\text { 18. RBF } 14-15-4\end{array}$ \\
\hline 2 & 1,100000 & $-0,63500$ & 2,89900 & $-15,0000$ & -31,0000 & 119,0000 & 518,000 & 2 & 2 & 0,000000 & 1,000000 & 0,000000 & 0,000000 \\
\hline 4 & 0,600000 & 0,04100 & 1,10000 & 0,0000 & $-14,0000$ & 175,0000 & 621,000 & 2 & 2 & 0,000000 & 1,000000 & 0,000000 & 0,000000 \\
\hline 7 & 0,000000 & $-0,02700$ & $-0,05800$ & 1,0000 & 0,0000 & 196,0000 & 162,000 & 4 & 4 & 0,030353 & 0,000000 & 0,004995 & 0,964652 \\
\hline 11 & 0,400000 & 0,67800 & $-1,39300$ & 1,0000 & 29,0000 & 174,0000 & 1045,000 & 1 & 1 & 0,931135 & 0,000000 & 0,000587 & 0,068278 \\
\hline 12 & 0,200000 & $-0,05800$ & $-0,26200$ & 0,0000 & 1,0000 & 99,0000 & 741,000 & 2 & 2 & 0,000000 & 0,998196 & 0,000000 & 0,001804 \\
\hline 13 & 2,900000 & $-1,02000$ & 6,79400 & $-35,0000$ & $-69,0000$ & 115,0000 & 293,000 & 3 & 3 & 0,009578 & 0,000000 & 0,866462 & 0,123960 \\
\hline 14 & 2,900000 & 0,48700 & $-6,22800$ & 5,0000 & 94,0000 & 174,0000 & 226,000 & 3 & 3 & 0,000000 & 0,000000 & 1,000000 & 0,000000 \\
\hline 17 & 0,100000 & 0,15900 & $-0,26500$ & 7,0000 & 3,0000 & 72,0000 & 1615,000 & 1 & 1 & 1,000000 & 0,000000 & 0,000000 & 0,000000 \\
\hline 18 & 0,100000 & $-0,02900$ & 0,23000 & $-1,0000$ & $-6,0000$ & 157,0000 & 1732,000 & 1 & 1 & 0,999996 & 0,000000 & 0,000004 & 0,000000 \\
\hline
\end{tabular}

Figure 12 - Indexes of network trust level №18

One more idea to be highlighted relates to the question that analysis of the sensitivity of parameter factors has the tendency of $\Delta$ indicating as the most significant one for the classification using artificial neural networks. The further following proposed table of weights reflects the same idea (Table 5).

Considering the application of the classification results for the functioning of the DSS, it is safe to look upon 


\begin{tabular}{|c|c|c|}
\hline \multicolumn{3}{|c|}{ Table 5 - Weights of network №18 } \\
\hline $\begin{array}{l}\text { Weights } \\
\text { ID }\end{array}$ & $\begin{array}{c}\text { Connections } \\
\text { 13.RBF 14-15-4 }\end{array}$ & $\begin{array}{l}\text { Weight values } \\
\text { 18.RBF 14-15-4 }\end{array}$ \\
\hline 1 & LAT - hidden neuron 1 & 0,00 \\
\hline 2 & LON - hidden neuron 1 & 0,40 \\
\hline 3 & COG - hidden neuron 1 & 0,63 \\
\hline 4 & SOG - hidden neuron 1 & 0,36 \\
\hline 5 & HDG - hidden neuron 1 & 0,57 \\
\hline 6 & LOG - hidden neuron 1 & 0,36 \\
\hline 7 & SET - hidden neuron 1 & 0,94 \\
\hline 3 & DRIFT - hidden neuron 1 & 0,10 \\
\hline 9 & SPD F - hidden neuron 1 & 0,42 \\
\hline 10 & SPD A - hidden neuron 1 & 0,55 \\
\hline 11 & RUD - hidden neuron 1 & 0,47 \\
\hline 12 & ROT - скрытый нейрон 1 & 0,35 \\
\hline 13 & RPM L-hidden neuron 1 & 0,00 \\
\hline 14 & $\Delta$ - hidden neuron & 1,00 \\
\hline
\end{tabular}

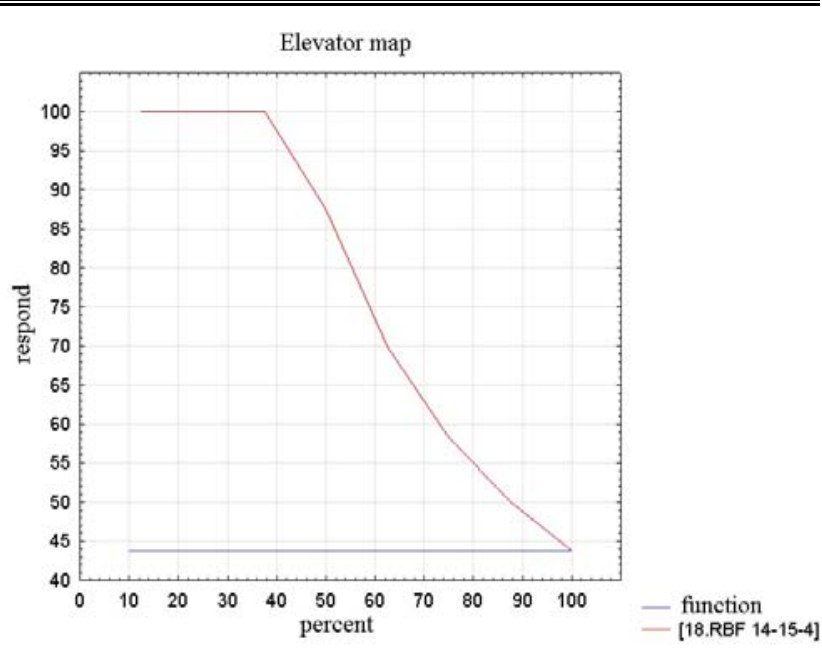

a

$1 \_\mu, \Delta, \mu$

[18.RBF 14-15-4]

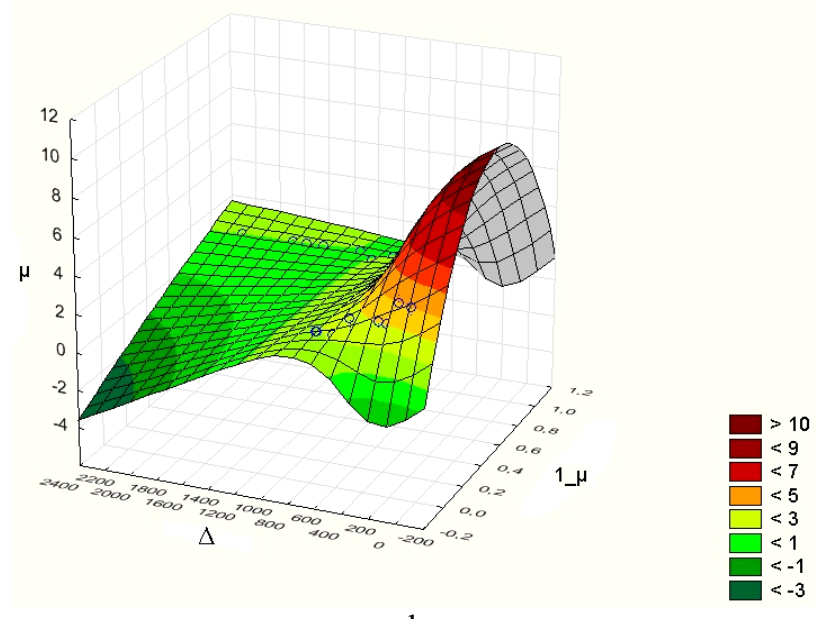

b

Figure 13 - Confidence level chart for $\mu_{1}$ $\left(4 \_\mu\right), \Delta, \mu$ [18.RBF 14-15-4]

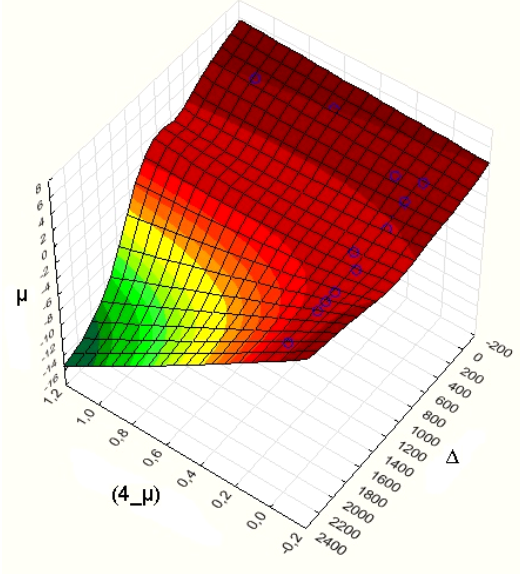

Figure 14 - Confidence level chart for $\mu_{4}$

the performing the maneuver $\mu_{1}$ as being the most effective strategy to be chosen. To prove the foregoing information an erroneous judgment of the skipper during the experimental survey is turning out to be a suitable and a reliable one.

This available data indicates an implicit predisposition to a distortion of the perception of navigational danger. This conclusion can be acquired being completely confirmed by elevators cards and 3D graphs of the confidence level in the Figure $13 \mathrm{a}, \mathrm{b}$.

As it clearly seen, the worst result is noticed to be $\mu_{4}$.

This issue being coherent and comprehensible enough can easily be clarified due to the fact that in most cases this strategy might not always be accurate and, as a result, might not be recommended for use in regular situations. To be exactly, turning with anchor drop is named to be the most effective one in emergency cases that threaten to collide with another vessel or land aground. To testify this the idea is illustrated by the proposed graphs (Fig. 14) Strategies $\mu_{2}$ and $\mu_{3}$ do not possess competitive nature with the given $\mu_{1}$ being located in an intermediate position between $\mu_{1}$ and $\mu_{4}$.

Obviously, with an aim to fulfill the DSS forecast, a broader skipper model must meet the needs to be revealed paying close attention to the question of having this issue classified by a sufficient number of locations with a target to predict its perception of behavior anywhere in the world.

It is certain enough to say that a large and long-term analysis by both the DSS and the staff of the Kheson State Maritime Academy is highly requested to be fulfilled.

Besides, these minor approaches might be dealt with and settled up apparently as they are highly likely to prevent the negative consequences of distortion in the perception of navigational danger by cadets during internships and directly during performing navigation tasks and controlling the vessel process.

(C) Nosov P. S., Zinchenko S. M., Popovych I. S., Ben A. P., Nahrybelnyi Y. A., Mateichuk V. M., 2020 DOI 10.15588/1607-3274-2020-1-15 


\section{RESULTS}

It is certain to underline that the approaches to identifying navigational hazards are based mostly on probabilistic models and a formal description in the framework of set theory was critically examined and analyzed. The proposed above strategy is named to be justified making it possible to bring out and set interrelation between the concepts of situation perception, location features and probable risks.

In addition there is a need to add that the applied criteria for constructing an incomplete model of perception by a operator of dangers is mostly limited by inaccuracies and subjective experimental relationships regarding the local metric of the transition of the vessel in the nearest interaction radius.

Furthermore, a DSS operation scheme is proposed to be undertaken. This item involves variety of factors to be observed that prone to influence on operator decision making, as well as a formal algorithm for test identification of operator preferences when choosing and setting a resulting strategy based on Pareto efficiency theory upper bounds for optimal alternatives.

Therefore, an experiment is announced to have been conducted on the basis of an automated analysis relating to the point of the strategies choice being accomplished by the operator when performing maneuvers based on data from logfiles for 2.5 years period. The processed data by means of artificial neural networks happened to illustrate nonrandom dependencies that form class-forming sets of parameters and to indicate in an acceptable way an erroneous perception of the situation in difficult conditions.

Basing on the following, eventually, having been received results of the experimental data processing, the proposed models and algorithms welcomed the introduction of identification process of the stable models of operator behavior in critical situations. The outcome was managed to be obtained practically through experience. Consequently, this practice provided assistance to us in operation of constructing a DSS with the ability to deliver prediction and to prevent negative consequences in maritime transport as well as to build an individual operator model in the form of a preference map.

\section{DISCUSSION}

The developed models and algorithms succeed in empowering to exclude the negative manifestations of stable preferences of the operator when choosing a maneuvering strategy in tight spaces.

To conclude, it could be argued that due to the results of modeling and analysis of the experimental data of the Navi Trainer 5000 navigation simulator the proposed formal approaches and software lead the way to high level determining of possible errors in perceiving dangers from the side of the operator and, as a result, to prevention of catastrophes when performing complex maneuvers.

\section{CONCLUSIONS}

It can be summarized that models and algorithms for identifying distortions in the perception of dangers by the operator during the execution of complex maneuvers are reported to be defined.

The results of the experiment using NTPRO 5000, as well as the developed software, enable us to reveal the subjective errors in making managerial decisions made by the operator. Identification is grounded on the ratio of adaptive test results based on Pareto-optimal alternatives for preference and, as for classification, it is grounded on artificial neural networks. It thus became beneficial to create the environment likely to have the criteria defined for the formation of an information model of the operator in the conditions of partial watch team and the realization of complex maneuvers.

So, the further improvement which can be strongly supported lies in the area of the development of DSS [34] software on the ground of the proposed models and algorithms for detecting deviations in the perception of navigational hazards. Basing on these investigations the level of safety of watch keeping in the condition of its incompleteness can be significantly increased.

Special emphasis must be added to the point of introducing an algorithm, which is considered to be a scientific novelty. It is the effective and reasonable way, from one point of view, to provide possibility to identify stable subjective connections that affect the adequate perception of the navigation situation and, from another one, to forecast the performance of similar maneuvers based on classification analysis.

The practical relevance of the research, in fact, is reported to depict that the results of the experiment, as well as the developed software, are drafted in such a way as to make it possible to identify preferences in the choice of strategies and their modifications as well as to separate the uncertain actions of the operator from the actions verified many times. In view of this fact, random positive maneuvering results from the side of the operator are found out to be advantageous enough being characterized by a spontaneous choice of strategy and, by the way, they do not guarantee success under similar conditions in the future. These spoken above developments are broadly looked at as being worthwhile for reinforcing the skills of cadets of naval academies during training simulations on navigation simulators.

One more issue to be paid attention to is that further proposed way of prospects is certain to be preceding to the development of methods for eliminating erroneous decision-making principles when choosing maneuvering strategies managing a vessel.

\section{ACKNOWLEDGEMENTS}

The work is carried out within the framework of "Development of software for important the quality of functioning systems for dynamic position sea vessels" (state registration number 0119U100948), of navigation and ECDIS departments of Kherson State Maritime Academy Navigation Faculty (scientific adviser: Ph.D. Associate Professor, Deputy Rector for scientific and pedagogical work, Kherson State Maritime Academy, Ukraine, Ben A.P.). 


\section{REFERENCES}

1. Puisa R., Lin L., Bolbot V. et al. Unravelling causal factors of maritime incidents and accidents, Safety Science, 2018 Vol. 110(A), pp. 124-141. DOI: 10.1016/j.ssci.2018.08.001.

2. Tran N. K., Haasis H. D. A research on operational patterns in container liner shipping, Transport, 2018, Vol. 33, Issue 3, pp. 619-632. DOI: 10.3846/transport.2018.1571.

3. Topolšek D., Dragan D. Relationships between the motorcyclists' behavioural perception and their actual behavior, Transport, 2018, Vol. 33, Issue 1, pp. 151-164. DOI: 10.3846/16484142.2016.1141371.

4. Nosov P. S., Palamarchuk I. V., Safonov M. S. et al. Modeling the manifestation of the human factor of the maritime crew, Science and transport progress, 2018, Vol. 5, Issue 77, pp. 82-92. DOI:10.15802/stp2018/ 147937.

5. Pytev Yu. M. Reliability of interpretation of an experiment based on an approximate model, Math modeling, 1989, Vol. 1, Issue 2, pp. 49-64.

6. Stepantsov M. E. Mathematical model for the directed motion of a people group, Math modeling, 2004, Vol. 16, Issue 3, pp. 43-49.

7. [Nosov P. S., Ben A. P., Matejchuk V. N. et al. Identification of "Human error" negative manifestation in maritime transport, Radio Electronics, Computer Science, Control, 2018, Vol. 4, Issue 47, pp. 204-213. DOI: 10.15588/16073274-2018-4-20

8. Bole A., Wall A., Norris A. Navigation Techniques Using Radar and ARPA, Radar and ARPA Manual: Third Edition. Butterworth-Heinemann, 2014, pp. 371-405. DOI: 10.1016/B978-0-08-097752-2.00008-8.

9. Zinchenko S. M., Nosov P. S., Mateichuk V. M. et al. Use of navigation simulator for development and testing ship control systems, The international scientific and practical conference dedicated to the memory of professors Fomin Y. $Y$. and Semenov V. S. Odessa. Stambul, 24-28 April 2019, proceedings. ONMU, 2019, pp. 350-355.

10. Shiqi F., Jinfen Z., Eduardo B. D. et al. Effects of seafarers emotion on human performance using bridge simulation, Ocean Engineering, 2018, Vol. 170, pp. 111-119. DOI: 10.1016/j.oceaneng.2018. 10.021.

11. Popovych I. S., Blynova O. Ye. The structure, variables and interdependence of the factors of mental states of expectations in students' academic and professional activities, The New Educational Review, 2019, Vol. 55, Issue 1, pp. 293306. DOI: 10.15804/ tner.2019.55.1.24.

12. COLREGS - International Regulations for Preventing Collisions at Sea [Electronic resource]. Access mode: http://www.jag.navy.mil/distrib/instructions/COLREG -1972.pdf

13. Xi Y., Yang Z., Fang Q. et al. A new hybrid approach to human error probability quantification-applications in maritime operations, Ocean Engineering, 2017, Vol. 138, pp. 45-54. DOI: 10.1016/j.oceaneng.2017. 04.018.

14. Akyuz E. Quantitative human error assessment during abandon ship procedures in maritime transportation, Ocean Engineering, 2016, Vol. 120, pp. 21-29. DOI:10.1016/j.oceaneng.2016.05. 017.

15. Park Y. A., Yip T. L., Park H. G. An Analysis of Pilotage Marine Accidents in Korea, The Asian Journal of Shipping and Logistics, 2019, Vol. 35, Issue 1, pp. 49-54. DOI: 10.1016/j.ajsl.2019.03.007.

16. Nosov P., Ben A., Safonova A. et al. Formal going approaches to determination periods of intuitional behavior of navigator during supernumerary situations, Radio Electron- ics, Computer Science, Control, 2019, Vol. 2, Issue 49, pp. 140-150. DOI: 10.15588/1607-3274-2019-2-15.

17. Pauer G., Sipos T., Török Á. Statistical analysis of the effects of disruptive factors of driving in simulated environment, Transport, 2019, Vol. 34, Issue 1, P. 1-8. DOI: 10.3846/transport. 2019.6724.

18. Szlapczynski R., Krata P. Determining and visualizing safe motion parameters of a ship navigating in severe weather conditions, Ocean Engineering, 2018, Vol. 158, pp. 263 274. DOI: 10.1016/ j.oceaneng. 2018.03.092.

19. Rolf J., Asbjorn B., Aalberg L. Maritime navigation accidents and risk indicators: An exploratory statistical analysis using AIS data and accident reports, Reliability Engineering \& System Safety, 2018, Vol. 176, pp. 174-186. DOI: 10.1016/j.ress.2018. 03.033 .

20. Guidance notes on safety culture and leading indicators of safety, American Bureau of Shipping, 2012. Houston, Vol. 74.

21. Berg H. P. Human Factors and Safety Culture in Maritime Safety, The International Journal on Marine Navigation and Safety of Sea Transportation, 2013, Vol. 7, Issue 3, pp. 343352. DOI: 10.12716/1001.07.03.04.

22. Ventikos N., Papanikolaou A., Louzis K. et al. Statistical analysis and critical review of navigational accidents in adverse weather conditions, Ocean Engineering, 2018, Vol. 163, pp. 502-517. DOI: 10.1016/j.oceaneng. 2018.06.001.

23. [Paulauskas V., Paulauskas D., Plačienė B. et al. Ship mooring to jetties under the crosscurrent, Transport, 2018, Vol. 33, Issue 2, P. 454-460, DOI: 10.3846/ 16484142.2017.1354069.

24. Jech T. Set theory. Berlin, Springer, 1997, 753 p. DOI: 10.1007/3-540-44761-X

25. Roger B. Myerson. Game Theory: Analysis of Conflict. Harvard, 1991, 600 p.

26. Bain L. Introduction to Probability and Mathematical Statistics / L. J. Bain, M. Engelhardt. - Belmont : Duxbury Press, 1992. $-648 \mathrm{p}$.

27. Popovych I. S. Social expectations - a basic component of the system of adjusting of social conduct of a person, Australian Journal of Scientific Research, 2014, Vol. 2, Issue 6, pp. 393-398.

28. Dinh G. H. The combination of analytical and statistical method to define polygonal ship domain and reflect human experiences in estimating dangerous area, International Journal of e-Navigation and Maritime Economy, 2016, Vol. 4, pp. 97-108, DOI: 10.1016/j.enavi. 2016.06.009.

29. Olijnik A. O., Skrupskij S. Yu., Subbotin S. O. et al. Planuvannya resursiv paralelnoyi obchislyuvalnoyi sistemi pri sintezi nejronechitkih modelej dlya obrobki velikih danih, Radio Electronics, Computer Science, Control, 2016, Vol. 4. pp. 61-69. DOI 10.15588/1607-3274-2016-4-8.

30. Heiko R. The complexity of Nash equilibria, local optima, and Pareto-optimal solutions: thesis Doktors der Naturwissenschaften genehmigte Dissertation. RheinischWestf'alischen, Erlangung, 2008, $171 \mathrm{p}$.

31. Prokopchuk Y. A. Sketch of the formal theory of creativity / Dnepr, PSACEA Press, 2017, 452 p.

32. Panin V. V., Doronin V. V., Spiyan O. M. Construction of a neural network expert system for navigation data processing in terms of river e-navigation, Radio Electronics, Computer Science, Control, 2019, Vol. 1, pp. 203-217. DOI 10.15588/1607-3274-2019-1-19.

33. De Luca M. A comparison between prediction power of artificial neural networks and multivariate analysis in road 
safety management, Transport, 2017, Vol. 32, Issue 4, pp. 379-385, DOI: $10.3846 / 16484142.2014 .995702$.

34. Firsov S. N., Pishchukhina O. A. Intelligent support of multilevel functional stability of control and navigation systems
Radio Electronics, Computer Science, Control, 2018, Vol. 2. pp. 177-183. DOI 10.15588/1607-3274-2018-2-20.

Received 11.09.2019.

Accepted 30.12.2019.

УДК 004.942: 316.454 .54

\section{СИСТЕМА ДІАГНОСТИКИ СПРИЙНЯТТЯ НАВІГАЦЙНОЇ НЕБЕЗПЕКИ ПІД ЧАС ВИКОНАННЯ СКЛАДНИХ} МАНЕВРІВ

Носов П. С. - канд. техн. наук, доцент кафедри судноводіння і електронних навігаційних систем, Херсонська державна морська академія, Україна.

Зінченко С. М. - канд. техн. наук, старший викладач кафедри управління судном, завідувач лабораторією електронних симуляторів, Херсонська державна морська академія, Україна.

Попович I. С. - д-р пед. наук, доцент кафедри загальної та соціальної психології, Херсонський державний університет, Україна.

Бень А. П. - канд. техн. наук, доцент, заступник ректора з науково-педагогічної роботи, Херсонська державна морська академія, Україна.

Нагрибельний Я. А. - канд. істор. наук, декан факультету судноводіння, Херсонська державна морська академія, Україна.

Матейчук В. М. - аспірант, завідувач лабораторією електронних симуляторів, Херсонська державна морська академія, Україна.

\section{АНОТАЦІЯ}

Актуальність. У статті розглядається задача автоматизованого аналізу прийняття рішень оператором в ергатичних системах критичних інфраструктур на прикладі управління морським транспортом в складних навігаційних умовах. Основним критерієм адекватного сприйняття вхідної інформації оператором є прогнозування поведінкових стратегій прийняття рішень в умовах дискретного часу. Однак, складність моделювання дій оператора полягає у нелінійному формуванні рішень в умовах позаштатних ситуацій і відхилень від Кодексів і Правил.

Мета. Метою дослідження $є$ розробка математичного забезпечення модуля системи підтримки прийняття рішень (СППР) для ідентифікації класоутворюючих множин атомарних елементів що визначають факт спотворення сприйняття інформації про навігаційні ризики шляхом формального аналізу і прогнозу моделей поведінки оператора при управлінні судном.

Метод. 3 метою автоматизації аналізу сприйняття небезпеки оператором, була побудована математична модель, яка ідентифікує факт спотворення сприйняття у вигляді простору ознак метаданих, що одержуються за допомогою обробки інформації навігаційних приладів. Фактором дезорієнтації оператора також може служити несення вахти на зміщеному містку, що істотно впливає на аналіз інформації для адекватного прийняття рішень. У зв'язку з порушенням синхронізації навігаційних приладів, таких як: РЛC, ARPA, AIC, ECDIS, особливо у випадках виходу з режиму автоматичного управління, виникає небезпечний прецедент що полягає у неготовності оператора сприйняти складність ситуації, внаслідок чого проведено формальний аналіз на предмет підвищення ризиків під час переходу у вказаних умовах. Також побудована імовірнісна модель сприйняття ситуації в умовах картежа похибок. Моделювання показало, що без чіткої ідентифікації факторів, що впливають на спотворення сприйняття оператора, неможливо визначити ступінь критичності навігаційної ситуації, тому узагальнених статистичних даних недостатньо і для результативної роботи СППР, тобто необхідна індивідуальна інформаційна модель кожного оператора. 3 метою аналізу сприйняття інформації оператором був розроблений тест, що визначає переваги при виборі стратегії керуючих впливів у вигляді виконання маневру при складних навігаційних умовах. Результати тестування, а також дані по проходженню локації дозволили виконати класифікаційний аналіз по 15 параметрам за допомогою штучних нейронних мереж і визначити межі відхилень у сприйнятті навігаційної небезпеки. У ядро СППР внесений ряд правил і алгоритмів, які включають: поле взаємодії, засоби синхронізації РЛС і НІС; фактична навігаційна небезпека в даній картографічній області; траєкторії руху суден i, як результат, моделювання імовірного відхилення у сприйнятті оператора.

Результати. 3 метою підтвердження результативності розробленої СППР і запропонованих формально-аналітичних підходів був проведений експеримент із застосуванням навігаційного тренажера Navi Trainer 5000 (NTPRO 5000). Метадані експерименту за 2,5 року роботи навігаційних тренажерів і програмних засобів СППР дозволили ідентифікувати ймовірність відхилення в інформаційному сприйнятті небезпек і експортувати прогнозовані дані в нові для оператора локації і картографічні райони. Проведений експеримент підтвердив гіпотезу дослідження і показав доцільність трансформаційних змін даної СППР для виконання прогнозів можливих ризиків при управлінні судном шляхом аналізу інформаційної моделі оператора.

Висновки. Представлені в дослідженні інформаційні та формально-аналітичні підходи, а також розроблені програмні засоби СППР дозволили виконати класифікацію стратегій прийняття рішень оператором при управлінні судном і спрогнозувати ймовірність катастрофічних наслідків. Проведені експерименти підтвердили доцільність запропонованих моделей $\mathrm{i}$ методів.

КЛЮЧОВІ СЛОВА: системи підтримки прийняття рішень; інформаційна модель оператора; комп'ютерні навігаційні симулятори; ймовірність ризиків; інформаційний аналіз людського фактора, автоматизовані системи управління, автоматичні системи управління. 


\section{СИСТЕМА ДИАГНОСТИКИ ВОСПРИЯТИЯ НАВИГАЦИОННОЙ ОПАСНОСТИ ПРИ ВЫПОЛНЕНИИ} СЛОЖНЫХ МАНЕВРОВ

Носов П. С. - канд. техн. наук, доцент кафедры судовождения и електронных навигационных систем, Херсонская государственная морская академия, Украина.

Зинченко С. Н. - канд. техн. наук, старший преподаватель кафедры управления судном, заведующий лабораторией электронных симуляторов, Херсонская государственная морская академия, Украина.

Попович И. С. - д-р пед. наук, доцент кафедры общей и социальной психологии, Херсонский государственный университет, Украина.

Бень А. П. - канд. техн. наук, доцент, заместитель ректора по научно-педагогической работе, Херсонская государственная морская академия, Украина.

Нагрибельный Я. А. - канд. истор. наук, декан факультета судовождения, Херсонская государственная морская академия, Украина.

Матейчук В. Н. - аспирант, заведующий лабораторией электронных симуляторов, Херсонская государственная морская академия, Украина.

\section{АННОТАЦИЯ}

Актуальность. В статье рассматривается задача автоматизированного анализа принятия решений оператором в эргатических системах критических инфраструктур на примере управления морским транспортом в сложных навигационных условиях. Основным критерием адекватного восприятия входной информации оператором является прогнозирование поведенческих стратегий принятия решений в условиях дискретного времени. Однако, сложность моделирования действий оператора состоит в нелинейном формировании решений в условиях внештатных ситуаций и отклонений от Кодексов и Правил.

Цель. Целью исследования является разработка математического обеспечения модуля системы поддержки принятия решений (СППР) для идентификации классо-образующего множества атомарных элементов, определяющих факт искажения восприятия информации о навигационных рисках путем формального анализа и прогноза моделей поведения оператора при управлении судном.

Метод. С целью автоматизации анализа восприятия опасности оператором, была построена математическая модель, которая идентифицирует факт искажения восприятия в виде признакового пространства метаданных, получаемых посредством преобразования информации навигационных приборов. Фактором дезориентации оператора также может служить несение вахты на смещенном мостике, что существенно влияет на анализ информации для адекватного принятия решений. В связи с нарушением синхронизации навигационных приборов, таких как: PЛC, ARPA, AIC, ECDIS, особенно в случаях выхода из режима автоматического управления, создается опасный прецедент неготовности оператора воспринять сложность ситуации вследствие чего проведен формальный анализ на предмет повышения рисков во время перехода в этих условиях. Также построена вероятностная модель восприятия ситуации в условиях картежа погрешностей. Моделирование показало, что без четкой идентификации факторов, влияющих на искажение восприятия оператора, невозможно определить степень критичности навигационной ситуации, поэтому обобщенных статистических данных недостаточно и для результативной работы СППР необходима индивидуальная информационная модель каждого оператора. С целью анализа восприятия информации оператором был разработан тест, определяющий предпочтения при выборе стратегии управляющих воздействий в виде выполнения маневра при сложных навигационных условиях. Результаты тестирования, а также данные по прохождению локаций позволили выполнить классификационный анализ по 15 параметрам с помощью искусственных нейронных сетей и определить границы отклонений в восприятии навигационной опасности. В ядро СППР внесен ряд правил и алгоритмов, включающие: поле взаимодействия, средства синхронизации РЛС и НИС; фактическая навигационная опасность в данной картографической области; траектории движения судов и, как результат, моделирования вероятного отклонения в информационном восприятии оператора.

Результаты. С целью подтверждения результативности разработанной СППР и предложенных формальноаналитических подходов был проведен эксперимент с применением навигационного тренажера Navi Trainer 5000 (NTPRO 5000). Метаданные эксперимента за 2,5 года работы навигационных тренажеров и программные средства СППР позволили идентифицировать вероятность отклонения в информационном восприятии опасностей и экспортировать прогнозированные данные в новые для оператора локации и картографические районы. Проведенный эксперимент подтвердил гипотезу исследования и показал целесообразность применения данной СППР для выполнения прогнозов возможных рисков при управлении судном путем анализа информационной модели оператора.

Выводы. Представленные в исследовании информационные и формально-аналитические подходы, а также разработанные программные средства СППР позволили выполнить классификацию стратегий принятия решений оператором при управлении судном и спрогнозировать вероятности катастрофических последствий. Проведенные эксперименты подтвердили целесообразность предложенных моделей и методов.

КЛЮЧЕВЫЕ СЛОВА: системы поддержки принятия решений; информационная модель оператора; компьютерные навигационные симуляторы; вероятность рисков; информационный анализ человеческого фактора, автоматизированные системы управления, автоматические системы управления.

\section{ЛІТЕРАТУРА / ЛИТЕРАТУРА}

1. Unravelling causal factors of maritime incidents and accidents [R. Puisa, L. Lin, V. Bolbot et al.] // Safety Science. - 2018. Vol. 110(A). - P. 124-141. DOI: 10.1016/j.ssci. 2018.08.001.
2. Tran N. K. A research on operational patterns in container liner shipping / N. K. Tran, H. D. Haasis // Transport. - 2018. - Vol. 33, Issue 3. - P. 619-632. DOI: 10.3846/transport. 2018.1571.

3. Topolšek, D. Relationships between the motorcyclists' behavioural perception and their actual behavior / D. Topolšek,

(C) Nosov P. S., Zinchenko S. M., Popovych I. S., Ben A. P., Nahrybelnyi Y. A., Mateichuk V. M., 2020

DOI 10.15588/1607-3274-2020-1-15 
D. Dragan // Transport. - 2018. - Vol. 33, Issue 1. - P. 151164. DOI: $10.3846 / 16484142.2016 .1141371$.

4. Modeling the manifestation of the human factor of the maritime crew / [P. S. Nosov, I. V. Palamarchuk, M. S. Safonov et al.] // Science and transport progress. - 2018. - Vol. 5, Issue 77. - P. 82-92. DOI:10.15802/stp2018/ 147937.

5. Пытьев Ю. М. Надежность интерпретации эксперимента, основанной на приближенной модели / Ю. М. Пытьев // Математическое моделирование. - 1989. - Том 1, Номер 2. - C. 49-64.

6. Степанцов М. Е. Математическая модель направленного движения группы людей / М. Е. Степанцов // Математическое моделирование. - 2004. - Том 16, Номер 3. - С. 43-49.

7. Identification of "Human error" negative manifestation in maritime transport / [P. S. Nosov, A. P. Ben, V. N. Matejchuk et al.] // Radio Electronics, Computer Science, Control. - 2018. Vol. 4, Issue 47. - P. 204-213. DOI: 10.15588/1607-32742018-4-20.

8. Bole A. Navigation Techniques Using Radar and ARPA / A. Bole // Radar and ARPA Manual: Third Edition / A. Bole, A. Wall, A. Norris. - Butterworth-Heinemann, 2014. - P. 371-405. DOI: 10.1016/B978-0-08-097752-2.00008-8.

9. Use of navigation simulator for development and testing ship control systems / $[\mathrm{S}$. M. Zinchenko, P. S. Nosov, V. M. Mateichuk at al.] // The international scientific and practical conference dedicated to the memory of professors Fomin Y. Y. and Semenov V. S., Odessa - Stambul, 24-28 April 2019, proceedings. - ONMU, 2019. - P. 350-355.

10. Effects of seafarers emotion on human performance using bridge simulation / [F. Shiqi, Z. Jinfen, B. D. Eduardo at al.] // Ocean Engineering. - 2018. - Vol. 170. - P. 111-119. DOI: 10.1016/j.oceaneng.2018. 10.021.

11. Popovych I. S. The structure, variables and interdependence of the factors of mental states of expectations in students' academic and professional activities / I. S. Popovych, O. Ye. Blynova // The New Educational Review. - 2019. Vol. 55, Issue 1. - P. 293-306. DOI:10.15804/ ther.2019.55.1.24.

12. COLREGS - International Regulations for Preventing Collisions at Sea [Electronic resource]. - Access mode: http://www.jag.navy.mil/distrib/instructions/COLREG-1972.pdf

13. A new hybrid approach to human error probability quantification-applications in maritime operations / [Y. Xi, Z. Yang, Q. Fang et al.] // Ocean Engineering. - 2017. - Vol. 138. - P. 45-54. DOI: 10.1016/j.oceaneng.2017. 04.018.

14. Akyuz E. Quantitative human error assessment during abandon ship procedures in maritime transportation / E. Akyuz // Ocean Engineering. - 2016. - Vol. 120. - P. 21-29. DOI:10.1016/j.oceaneng.2016.05. 017.

15. Park Y. A. An Analysis of Pilotage Marine Accidents in Korea / Y. A. Park, T. L. Yip, H. G. Park // The Asian Journal of Shipping and Logistics. - 2019. - Vol. 35, Issue 1. - P. 49-54. DOI: 10.1016/j.ajs1.2019.03.007.

16. Formal going approaches to determination periods of intuitional behavior of navigator during supernumerary situations / $[\mathrm{P}$ Nosov, A. Ben, A. Safonova at al.] // Radio Electronics, Computer Science, Control. - 2019. - Vol. 2, Issue 49. - P. 140-150. DOI: 10.15588/1607-3274-2019-2-15.

17. Pauer G. Statistical analysis of the effects of disruptive factors of driving in simulated environment / G. Pauer, T. Sipos, Á. Török // Transport. - 2019. - Vol. 34, Issue 1. - P. 1-8. DOI: 10.3846/transport. 2019.6724

18. Szlapczynski R. Determining and visualizing safe motion parameters of a ship navigating in severe weather conditions R. Szlapczynski, P. Krata // Ocean Engineering. - 2018. -
Vol. 158. - P. 263-274. DOI: 10.1016/ j.oceaneng. 2018.03.092

19. Rolf J. Maritime navigation accidents and risk indicators: An exploratory statistical analysis using AIS data and accident reports / J. Rolf, B. Asbjorn, L. Aalberg // Reliability Engineering \& System Safety. - 2018. - Vol. 176. - P. 174-186. DOI: 10.1016/j.ress.2018. 03.033.

20. Guidance notes on safety culture and leading indicators of safety / American Bureau of Shipping. - 2012. - Houston. Vol. 74.

21. Berg H. P. Human Factors and Safety Culture in Maritime Safety / H. P. Berg // The International Journal on Marine Navigation and Safety of Sea Transportation. - 2013. - Vol. 7, Issue 3. - P. 343-352. DOI: 10.12716/1001.07.03.04.

22. Statistical analysis and critical review of navigational accidents in adverse weather conditions / [N. Ventikos, A. Papanikolaou, K. Louzis at al.] // Ocean Engineering. - 2018. - Vol. 163. P. 502-517. DOI: 10.1016/j.oceaneng. 2018.06.001.

23. 23. Ship mooring to jetties under the crosscurrent / [V. Paulauskas, D. Paulauskas, B. Plačienè at al.] // Transport. - 2018. Vol. 33, Issue 2. - P. 454-460, DOI: 10.3846/16484142. 2017.1354069.

24. Jech T. Set theory / T. Jech. - Berlin : Springer, 1997. $-753 p$. DOI: $10.1007 / 3-540-44761-X$.

25. Roger B. Game Theory: Analysis of Conflict / B. Roger, Myerson. - Harvard, 1991. $-600 \mathrm{p}$

26. Bain L. Introduction to Probability and Mathematical Statistics / L. J. Bain, M. Engelhardt. - Belmont: Duxbury Press, 1992. $648 \mathrm{p}$.

27. Popovych I. S. Social expectations - a basic component of the system of adjusting of social conduct of a person / I. S. Popovych // Australian Journal of Scientific Research. 2014. Vol. 2, Issue 6. - P. 393-398.

28. Dinh G. H. The combination of analytical and statistical method to define polygonal ship domain and reflect human experiences in estimating dangerous area / G. H. Dinh, N. K. Im // International Journal of e-Navigation and Maritime Economy. 2016. - Vol. 4. - P. 97-108. DOI: 10.1016/j.enavi. 2016.06.009.

29. Планування ресурсів паралельної обчислювальної системи при синтезі нейро-нечітких моделей для обробки великих даних / [А. О. Олійник, С. Ю. Скрупський, С. О. Субботін та ін.] // Radio Electronics, Computer Science, Control. - 2016. - Том. 4. - C. 61-69. DOI 10.15588/ 1607-3274-2016-4-8

30. Heiko R. The complexity of Nash equilibria, local optima, and Pareto-optimal solutions: thesis Doktors der Naturwissenschaften genehmigte Dissertation / R"oglin Heiko. - Rheinisch - Westf"alischen: Erlangung, 2008. - 171 p.

31. Прокопчук Ю. А. Набросок формальной теории творчества / Ю. А. Прокопчук.- Днепр : ГВУЗ «ПГАСА», 2017. - 452 с.

32. Панін В. В. Побудова нейромережевої експертної системи обробки навігаційних даних в умовах річкової е-навігації / В. В. Панін, В. В. Доронін, О. М. Спіян // Радіоелектроніка, інформатика, управління. - 2019. - Том. 1. - С. 203-217. DOI 10.15588/1607-3274-2019-1-19.

33. De Luca M. A comparison between prediction power of artificial neural networks and multivariate analysis in road safety management / M. De Luca // Transport. - 2017. -Vol. 32, Issue 4. - P. 379-385, DOI: 10.3846/ 16484142.2014.995702.

34. Firsov S. N. Intelligent support of multilevel functional stability of control and navigation systems / S. N. Firsov, O. A. Pishchukhina // Радіоелектроніка, інформатика, управління. - 2018. - Vol. 2. - P. 177-183. DOI 10.15588/1607$3274-2018-2-20$ 